\title{
Effect of dietary cation-anion difference on acid-base status and dry matter intake in dry pregnant cows
}

\author{
R. Zimpel, ${ }^{\star} \dagger$ M. B. Poindexter, ${ }^{\star}$ A. Vieira-Neto, ${ }^{\star} \dagger$ E. Block, $\ddagger$ C. D. Nelson, ${ }^{*}$ C. R. Staples, ${ }^{*}$ W. W. Thatcher, ${ }^{*} \dagger$ \\ and J. E. P. Santos* ${ }^{1}$ \\ ${ }^{*}$ Department of Animal Sciences, and \\ †DH Barron Reproductive and Perinatal Biology Research Program, University of Florida, Gainesville 32611 \\ $\ddagger$ Arm and Hammer Animal Nutrition, Princeton, NJ 08540
}

\section{ABSTRACT}

The objective was to determine if the reduction in dry matter (DM) intake of acidogenic diets is mediated by inclusion of acidogenic products, content of salts containing $\mathrm{Cl}$, or changes in acid-base status. The hypothesis was that a decrease in intake is mediated by metabolic acidosis. Ten primigravid Holstein cows at $148 \pm 8 \mathrm{~d}$ of gestation were used in a duplicated $5 \times$ 5 Latin square design. The dietary cation-anion difference (DCAD) of diets and acid-base status of cows were manipulated by incorporating an acidogenic product or by adding salts containing $\mathrm{Cl}, \mathrm{Na}$, and $\mathrm{K}$ to the diets. Treatments were a base diet $(\mathrm{T} 1 ; 1.42 \% \mathrm{~K}, 0.04 \% \mathrm{Na}$, $0.26 \% \mathrm{Cl} ; \mathrm{DCAD}=196 \mathrm{mEq} / \mathrm{kg})$; the base diet with added $1 \% \mathrm{NaCl}$ and $1 \% \mathrm{KCl}(\mathrm{T} 2 ; 1.83 \% \mathrm{~K}, 0.42 \% \mathrm{Na}$, $1.23 \% \mathrm{Cl} ; \mathrm{DCAD}=194 \mathrm{mEq} / \mathrm{kg}$ ); the base diet with added $7.5 \%$ acidogenic product, $1.5 \% \mathrm{NaHCO}_{3}$, and $1 \%$ $\mathrm{K}_{2} \mathrm{CO}_{3}(\mathrm{~T} 3 ; 1.71 \% \mathrm{~K}, 0.54 \% \mathrm{Na}, 0.89 \% \mathrm{Cl} ; \mathrm{DCAD}=$ $192 \mathrm{mEq} / \mathrm{kg}$ ); the base diet with added $7.5 \%$ acidogenic product $(\mathrm{T} 4 ; 1.29 \% \mathrm{~K}, 0.13 \% \mathrm{Na}, 0.91 \% \mathrm{Cl}$; DCAD = $-114 \mathrm{mEq} / \mathrm{kg}$ ); and the base diet with $7.5 \%$ acidogenic product, $1 \% \mathrm{NaCl}$, and $1 \% \mathrm{KCl}(\mathrm{T} 5 ; 1.78 \% \mathrm{~K}, 0.53 \%$ $\mathrm{Na}, 2.03 \% \mathrm{Cl}$; DCAD $=-113 \mathrm{mEq} / \mathrm{kg}$ ). Periods lasted $14 \mathrm{~d}$ with the last $7 \mathrm{~d}$ used for data collection. Feeding behavior was evaluated for $12 \mathrm{~h}$ in the last $2 \mathrm{~d}$ of each period. Reducing the DCAD by feeding an acidogenic product reduced blood $\mathrm{pH}(\mathrm{T} 1=7.450$ vs. $\mathrm{T} 2=7.436$ vs. $\mathrm{T} 3=7.435$ vs. $\mathrm{T} 4=7.420$ vs. $\mathrm{T} 5=7.416)$ and induced a compensated metabolic acidosis with a reduction in bicarbonate, base excess, and partial pressure of $\mathrm{CO}_{2}$ in blood, and reduced $\mathrm{pH}$ and strong ion difference in urine. Reducing the DCAD reduced DM intake 0.6 $\mathrm{kg} / \mathrm{d}(\mathrm{T} 1=10.3$ vs. $\mathrm{T} 4=9.7 \mathrm{~kg} / \mathrm{d})$, which was caused by the change in acid-base status $(\mathrm{T} 2+\mathrm{T} 3=10.2$ vs. $\mathrm{T} 4+\mathrm{T} 5=9.6 \mathrm{~kg} / \mathrm{d}$ ) because counteracting the acidi-

Received March 14, 2018.

Accepted May 17, 2018.

${ }^{1}$ Corresponding author: jepsantos@ufl.edu fying action of the acidogenic product by adding salts with strong cations to the diet prevented the decline in intake. The decline in intake caused by metabolic acidosis also was observed when adjusted for body weight $(\mathrm{T} 2+\mathrm{T} 3=1.75$ vs. $\mathrm{T} 4+\mathrm{T} 5=1.66 \% \mathrm{BW})$. Altering the acid-base status with acidogenic diets reduced eating $(\mathrm{T} 2+\mathrm{T} 3=6.7$ vs. $\mathrm{T} 4+\mathrm{T} 5=5.9$ bouts $/ 12$ h) and chewing ( $\mathrm{T} 2+\mathrm{T} 3=14.6$ vs. $\mathrm{T} 4+\mathrm{T} 5=13.5$ bouts $/ 12 \mathrm{~h}$ ) bouts, and extended meal duration ( $\mathrm{T} 2+$ $\mathrm{T} 3=19.8$ vs. $\mathrm{T} 4+\mathrm{T} 5=22.0 \mathrm{~min} / \mathrm{meal})$ and intermeal interval $(\mathrm{T} 2+\mathrm{T} 3=92.0$ vs. $\mathrm{T} 4+\mathrm{T} 5=107.7 \mathrm{~min})$. Results indicate that reducing the DCAD induced a compensated metabolic acidosis and reduced DM intake, but correcting the metabolic acidosis prevented the decline in DM intake in dry cows. The decrease in DM intake in diets with negative DCAD was mediated by metabolic acidosis and not by addition of acidogenic product or salts containing $\mathrm{Cl}$.

Key words: acid-base status, dietary cation-anion difference, dry cow, dry matter intake

\section{INTRODUCTION}

Hypocalcemia is an important metabolic disease that affects dairy cattle around parturition because many cows are unable to compensate the irreversible loss of $\mathrm{Ca}$ required for synthesis of colostrum and milk at the onset of lactation. Goff (2008) stated that clinical and subclinical hypocalcemia are considered gateway diseases that impair health and reduce productivity in the ensuing lactation. In fact, cows that develop clinical and subclinical hypocalcemia have increased risk of numerous other diseases in early lactation (Curtis et al., 1983; Martinez et al., 2012). Therefore, prevention of hypocalcemia should be a major goal of transition cow feeding programs.

A dietary strategy to minimize the risk of clinical and subclinical hypocalcemia is the manipulation of the mineral content of prepartum diets to induce a compensated metabolic acidosis by feeding acidogenic diets. 
Prepartum diets with negative DCAD reduce clinical and subclinical hypocalcemia in dairy cows (Ender et al., 1971; Block, 1984; Martinez et al., 2018b), and the prevention of hypocalcemia by acidogenic diets also reduces the risk of retained placenta and metritis and improves lactation performance in parous cows (Santos et al., 2018).

According to the USDA (2016), at least $28 \%$ of the dairy farms in the United States feed prepartum acidogenic diets to prevent hypocalcemia. The recommended range of DCAD in diets for prepartum cows has been suggested as -50 to $-150 \mathrm{mEq} / \mathrm{kg}$ (NRC, 2001), although the ideal DCAD has not been established to optimize health and performance. One issue with acidogenic diets is the depression in DMI (Charbonneau et al., 2006). Numerous experiments have shown that reducing the DCAD of prepartum diets depresses DMI in dairy cows (Joyce et al., 1997; Lopera et al., 2018; Martinez et al., 2018a). Charbonneau et al. (2006) calculated the DCAD assuming that $\mathrm{K}, \mathrm{Na}$, and $\mathrm{Cl}$ are equally absorbed, but absorption of $\mathrm{S}$ is only $60 \%$ of those of $\mathrm{K}, \mathrm{Na}$, and $\mathrm{Cl}$. According to their calculations, a reduction in DCAD of $300 \mathrm{mEq} / \mathrm{kg}$ (i.e., from 200 to $-100 \mathrm{mEq} / \mathrm{kg}$ of $\mathrm{DM}$ ) would result in a depression in DMI of $1.3 \mathrm{~kg} / \mathrm{d}$. The same diets calculated with the DCAD equation considering $\mathrm{S}$ with equal bioavailability to the other elements in the equation would result in a greater difference in DCAD. Theories proposed to explain the depression in DMI when diets with negative DCAD are fed include the unpalatable effect of the salt sources (Oetzel et al., 1988; Oetzel and Barmore, 1993) or a response to the metabolic acidosis induced by the strong anions incorporated into the diet (Vagnoni and Oetzel, 1998). Nonetheless, neither of those theories has been evaluated specifically.

Recently, we showed that the reduction in DMI in prepartum cows fed diets with acidogenic products was observed regardless of the product fed, either an acidogenic salt or a commercial product (Santos et al., 2018), suggesting that metabolic acidosis and not palatability might be the reason for the reduced intake. We hypothesized that depression in DMI induced by feeding diets with negative DCAD is mediated by changes in acid-base status and not because of inclusion of acidogenic product or salts containing $\mathrm{Cl}$. Thus, the objective was to determine if the decrease in DMI in cows fed acidogenic diets is mediated by the addition of acidogenic product, inclusion of salts containing $\mathrm{Cl}$, or induced by changes in acid-base balance.

\section{MATERIALS AND METHODS}

The experiment was conducted at University of Florida Dairy Unit (Hague, FL) from January to April of 2017 and all procedures with cows were approved by the Institutional Animal Care and Use committee of the University of Florida, protocol number 201709707. Throughout the manuscript, the terms salts containing $\mathrm{Cl}$ or $\mathrm{Cl}$ salts refer to the addition of $\mathrm{NaCl}$ and $\mathrm{KCl}$, which increased dietary $\mathrm{Cl}$ content but were expected not to alter the acid-base status of cows.

\section{Cows, Housing, and Feeding}

Ten primigravid Holstein cows were used. Cows averaged $( \pm \mathrm{SD}) 562 \pm 32 \mathrm{~d}$ of age, $148 \pm 8 \mathrm{~d}$ pregnant, and $523 \pm 29 \mathrm{~kg}$ of BW at enrollment. At completion of the 70-d experiment, cows averaged $632 \mathrm{~d}$ of age, 218 d pregnant, and $624 \pm 31 \mathrm{~kg}$ of BW.

Cows were housed in a cross-ventilated tiestall barn with individual feed bins and water troughs equipped with flow meters. Cows were moved to the experimental facilities $2 \mathrm{wk}$ before the beginning of the experiment to acclimate to the new environment and daily handling. Stalls had air mattresses bedded with sand, and bedding material was cleaned 4 times a day and replaced thrice a week. Cows were fed twice daily at 0800 and $1800 \mathrm{~h}$, and the amounts of feed offered to individual cows were adjusted once daily to ensure at least $5 \%$ orts, which were weighed before the morning feeding. Twice weekly, dietary ingredients were sampled and dried at $55^{\circ} \mathrm{C}$ for adjustment of amounts of DM to be offered daily.

\section{Experimental Design and Treatments}

The experiment was a replicated $5 \times 5$ Latin square design with treatment sequence balanced for carry-over. The 10 cows were stratified based on BW at enrollment and the 5 heaviest cows were assigned to one square, whereas the remaining 5 cows to the second square. The experiment consisted of periods of $14 \mathrm{~d}$, in which $\mathrm{d}$ 1 to 7 were for adaptation to dietary treatments and $d$ 8 to 14 were used for data collection.

The diets were offered as TMR and formulated to meet or exceed the metabolizable energy and protein requirements of a $550 \mathrm{~kg}$ primigravid Holstein cow to gain at least $1.2 \mathrm{~kg} / \mathrm{d}$ including conceptus when DMI averages $10 \mathrm{~kg} / \mathrm{d}$ (NRC, 2001). The DCAD (mEq/kg of DM) was calculated assuming exactly the same absorption for the strong ions with the following formula: $\mathrm{DCAD}=\left[\left(\mathrm{mEq}\right.\right.$ of $\mathrm{K}^{+}+\mathrm{mEq}$ of $\left.\mathrm{Na}^{+}\right)-(\mathrm{mEq}$ of $\mathrm{Cl}^{-}+\mathrm{mEq}$ of $\left.\mathrm{S}^{2-}\right)$ ]. Ingredients were analyzed a priori to design diets to contain either 200 or $-100 \mathrm{mEq} / \mathrm{kg}$, a difference of $300 \mathrm{mEq} / \mathrm{kg}$ of DM. After diets were prepared and analyzed, there were minor deviations from the expected DCAD and mineral concentrations. Concentrates and forages were the same in all diets, 
except for the inclusion of acidogenic product and minerals used to alter the DCAD and supply additional salts containing $\mathrm{Cl}$ (Table 1). The acidogenic product used (Bio-Chlor, Arm and Hammer Animal Nutrition, Princeton, NJ) is a fermentation product containing dried condensed extracted glutamic acid fermentation product, dried condensed corn fermentation solubles, processed grain by-products, and magnesium chloride. The product contains $9.1 \% \mathrm{Cl}$ and $3.6 \% \mathrm{~S}$ with a DCAD of $-3,884 \mathrm{mEq} / \mathrm{kg}$. Also, at the dietary inclusion in the current experiment, the acidogenic product has been shown to induce a compensated metabolic acidosis and depress DMI in prepartum cows (Lopera et al., 2018; Martinez et al., 2018a).

Treatments consisted of a diet without acidogenic product or added salts containing $\mathrm{Cl}$ or buffers to result in a positive DCAD of $+196 \mathrm{mEq} / \mathrm{kg}$ of $\mathrm{DM}$ (T1); a diet similar to T1, but including additional salts containing $\mathrm{Cl}, 1 \%$ of $\mathrm{NaCl}$ (Morton Salt, Inc., Chicago, IL) and $1 \%$ of $\mathrm{KCl}(95.3 \% \mathrm{KCl}$, Dyna-K, Mosaic Company, Lithia, FL) to increase $\mathrm{Cl}$, but result in a similar and positive DCAD of $+194 \mathrm{mEq} / \mathrm{kg}$ of $\mathrm{DM}$

Table 1. Ingredient composition and nutrient content of diets

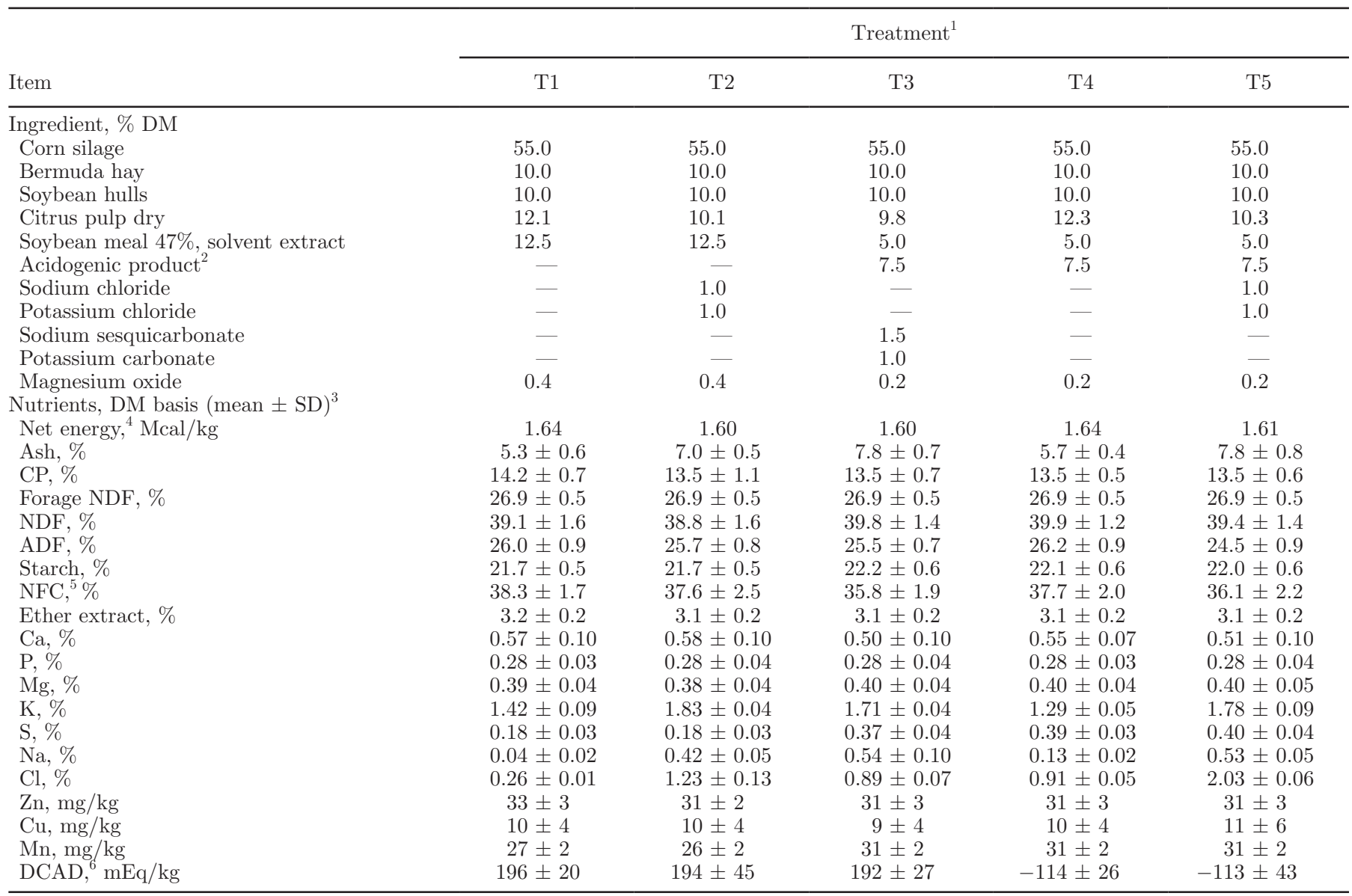

${ }^{1}$ Pregnant nulliparous Holstein cows were fed diets that differed in DCAD and supplemented with salts containing Cl when fed alkalogenic or acidogenic diets. T1 $=$ diet with DCAD of $+196 \mathrm{mEq} / \mathrm{kg}$ of DM without addition of salts containing $\mathrm{Cl}$; T2 = diet with DCAD of $+194 \mathrm{mEq} / \mathrm{kg}$ of

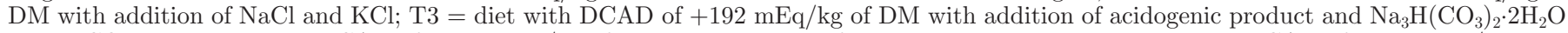
and $\mathrm{K}_{2} \mathrm{CO}_{3}$; T4 = diet with DCAD of $-114 \mathrm{mEq} / \mathrm{kg}$ of DM with addition of acidogenic product; T5 = diet with DCAD of $-113 \mathrm{mEq} / \mathrm{kg}$ with addition of acidogenic product, $\mathrm{NaCl}$, and $\mathrm{KCl}$.

${ }^{2}$ Bio-Chlor (fermentation product containing dried condensed extracted glutamic acid fermentation product, dried condensed corn fermentation solubles, processed grain by-products, and magnesium chloride; Arm and Hammer Animal Nutrition, Princeton, NJ).

${ }^{3}$ Samples of forages and grain mixtures collected and analyzed each period. Five representative samples of dietary ingredient were analyzed in duplicate for nutrient content.

${ }^{4}$ Calculated based on the chemical analysis of dietary ingredients and using the NRC (2001) for a DMI of $10.0 \mathrm{~kg} / \mathrm{d}$.

${ }^{5}$ Calculated using the equation DM - (CP + NDF + fat + ash - NDF insoluble protein).

${ }^{6}$ Dietary cation-anion difference calculated using the equation $\left[\left(\mathrm{mEq}\right.\right.$ of $\mathrm{Na}^{+}+\mathrm{mEq}$ of $\left.\mathrm{K}^{+}\right)-\left(\mathrm{mEq}\right.$ of $\left.\left.\mathrm{Cl}^{-}+\mathrm{mEq}^{-} \mathrm{S}^{2-}\right)\right]$. 
Table 2. Nutrient content of dietary ingredients on a DM basis

\begin{tabular}{|c|c|c|c|c|c|c|c|}
\hline Nutrient, mean $\pm \mathrm{SD}^{1}$ & $\begin{array}{l}\text { Corn } \\
\text { silage }\end{array}$ & $\begin{array}{c}\text { Bermuda } \\
\text { hay }\end{array}$ & \multicolumn{5}{|c|}{ Grain $\operatorname{mix}^{2}$} \\
\hline Ash, $\%$ & $3.8 \pm 0.3$ & $4.6 \pm 0.2$ & $7.8 \pm 1.1$ & $12.8 \pm 0.9$ & $15.1 \pm 1.4$ & $9.2 \pm 0.6$ & $15.1 \pm 1.7$ \\
\hline NDF, $\%$ & $36.5 \pm 0.9$ & $67.9 \pm 0.7$ & $35.0 \pm 3.1$ & $34.0 \pm 2.8$ & $37.0 \pm 2.5$ & $37.3 \pm 2.0$ & $36.0 \pm 2.3$ \\
\hline $\mathrm{ADF}, \%$ & $23.0 \pm 0.6$ & $37.4 \pm 2.3$ & $27.3 \pm 1.1$ & $26.6 \pm 0.8$ & $26.1 \pm 0.3$ & $27.9 \pm 1.0$ & $25.7 \pm 0.9$ \\
\hline Starch, \% & $36.8 \pm 0.5$ & $6.9 \pm 0.5$ & $2.3 \pm 0.1$ & $2.3 \pm 0.2$ & $3.6 \pm 0.1$ & $3.3 \pm 0.2$ & $3.2 \pm 0.2$ \\
\hline $\mathrm{Ca}, \%$ & $0.19 \pm 0.03$ & $0.48 \pm 0.03$ & $1.19 \pm 0.24$ & $1.22 \pm 0.22$ & $1.00 \pm 0.15$ & $1.15 \pm 0.16$ & $1.03 \pm 0.24$ \\
\hline $\mathrm{P}, \%$ & $0.21 \pm 0.02$ & $0.24 \pm 0.02$ & $0.42 \pm 0.07$ & $0.41 \pm 0.08$ & $0.40 \pm 0.08$ & $0.40 \pm 0.07$ & $0.40 \pm 0.08$ \\
\hline $\mathrm{Mg}, \%$ & $0.13 \pm 0.01$ & $0.21 \pm 0.01$ & $0.86 \pm 0.11$ & $0.84 \pm 0.12$ & $0.87 \pm 0.12$ & $0.89 \pm 0.11$ & $0.88 \pm 0.13$ \\
\hline $\mathrm{K}, \%$ & $1.21 \pm 0.03$ & $1.08 \pm 0.13$ & $1.85 \pm 0.16$ & $3.03 \pm 0.02$ & $2.67 \pm 0.04$ & $1.47 \pm 0.07$ & $2.88 \pm 0.17$ \\
\hline $\mathrm{Na}, \%$ & $0.02 \pm 0.01$ & $0.07 \pm 0.04$ & $0.07 \pm 0.03$ & $1.15 \pm 0.13$ & $1.50 \pm 0.25$ & $0.33 \pm 0.03$ & $1.47 \pm 0.13$ \\
\hline $\mathrm{Cl}, \%$ & $0.33 \pm 0.01$ & $0.55 \pm 0.05$ & $0.08 \pm 0.02$ & $2.83 \pm 0.35$ & $1.89 \pm 0.17$ & $1.94 \pm 0.12$ & $5.12 \pm 0.14$ \\
\hline S, $\%$ & $0.12 \pm 0.03$ & $0.23 \pm 0.02$ & $0.25 \pm 0.03$ & $0.25 \pm 0.04$ & $0.79 \pm 0.05$ & $0.86 \pm 0.04$ & $0.87 \pm 0.06$ \\
\hline
\end{tabular}

${ }^{1}$ Samples of forages and grain mixtures collected and analyzed each period. Five representative samples of dietary ingredient were analyzed in duplicate for nutrient content.

${ }^{2}$ Grain mixes fed in treatments 1 to 5 .

${ }^{3}$ Calculated using the equation $\mathrm{DM}-(\mathrm{CP}+\mathrm{NDF}+$ fat + ash $-\mathrm{NDF}$ insoluble protein $)$.

${ }^{4}$ Dietary cation-anion difference calculated using the equation $\left[\left(\mathrm{mEq}\right.\right.$ of $\mathrm{Na}^{+}+\mathrm{mEq}$ of $\left.\mathrm{K}^{+}\right)-\left(\mathrm{mEq}\right.$ of $\mathrm{Cl}^{-}+\mathrm{mEq}$ of $\left.\left.\mathrm{S}^{2-}\right)\right]$.

(T2); a diet with added $7.5 \%$ of acidogenic product, but also including $1.5 \%$ of sodium sesquicarbonate $\left(\mathrm{Na}_{2} \mathrm{CO}_{3} \cdot \mathrm{NaHCO}_{3} \cdot 2 \mathrm{H}_{2} \mathrm{O}\right.$, SQ-810 Arm \& Hammer Animal Nutrition) and $1.0 \%$ of $\mathrm{K}_{2} \mathrm{CO}_{3}$ (DCAD Plus, Arm and Hammer Animal Nutrition) to counteract the acidifying effects of the acidogenic product to result in the same positive DCAD of $+192 \mathrm{mEq} / \mathrm{kg}$ (T3); a diet with $7.5 \%$ added acidogenic product to reduce the DCAD by approximately $300 \mathrm{mEq} / \mathrm{kg}$ compared with the alkalogenic diets and to result in a DCAD of -114 $\mathrm{mEq} / \mathrm{kg}$ (T4); and an acidogenic diet similar to T4, but with additional $\mathrm{Cl}$ salts, $1 \%$ of $\mathrm{NaCl}$ and $1 \%$ of $\mathrm{KCl}$ (T5). Magnesium oxide (MAGOX, Premier Magnesia LLC, Overland Park, KS) $0.4 \%$ of DM for T1 and T2 and $0.2 \%$ of DM for T3, T4, and T5 was used to equalize the $\mathrm{Mg}$ content. Grain mixes were prepared once for the entire experiment and diets were mixed once daily, before the morning feeding, at $0800 \mathrm{~h}$.

\section{Ingredient Sampling and Analyses}

Samples of forages and concentrate mixtures were collected multiple times each period, dried in a forcedair oven at $55^{\circ} \mathrm{C}$ for $96 \mathrm{~h}$, moisture loss recorded, and ground to pass a 1-mm screen of a Wiley mill (Thomas Scientific, Swedesboro, NJ). Composite samples of each forage and grain mixture for each period were analyzed for their contents of DM $\left(105^{\circ} \mathrm{C}\right.$ for $\left.12 \mathrm{~h}\right), \mathrm{OM}\left(600^{\circ} \mathrm{C}\right.$ for $8 \mathrm{~h}$ ), sequential analysis of NDF using a heat stable

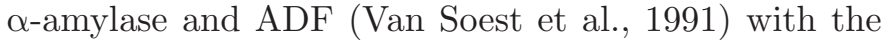
Ankom Fiber Analyzer system (Ankom Technology, Macedon, NY), starch according to Hall (2015), ether extract (method 920.39; AOAC, 1990), and N using an automated quantitative combustion digestion method (Elementar Analysensysteme, Elementar Americas Inc., Mt. Laurel, NJ). Reported values of NDF were corrected for ash. Contents of minerals were analyzed by inductively coupled plasma mass spectrometry at the Cumberland Valley Analytical Services Laboratory (Hagerstown, MD). The chemical composition of diets (mean $\pm \mathrm{SD}$ ) were calculated using the results of analyses of the forages and the respective grain mixes for each treatment (Table 2). The caloric densities of the diets were estimated using chemical analysis of dietary components and calculated for $10 \mathrm{~kg}$ of DMI using the NRC (2001) model (Table 1).

\section{DMI, Water Intake, BW, and Feeding Behavior}

The amounts of feed offered and refused were measured once daily throughout the experiment, and values from d 8 to 14 were used for statistical analysis. Cows were weighed on a walk-through scale (Tru-Test Inc., Mineral Wells, TX) on d 10 and 12 of each period at $1800 \mathrm{~h}$, and values were averaged within cow and period for statistical analyses. The intake of water (L/d) 
was measured daily throughout the experiment using individual water meters. Intakes of water from d 8 to 14 were used for statistical analysis.

Feeding behavior of all cows was evaluated during 2 consecutive days (d 13 and 14) of each period. On those days, the total amount of feed allotted daily was offered once, at $0800 \mathrm{~h}$. Cows were observed every 5 min by the same person in all 5 periods starting immediately after feeding for the next $12 \mathrm{~h}$ as described in Maltz et al. (2013) and also used in Dias et al. (2018). The activity of each cow was recorded as ruminating standing, ruminating lying, standing only, lying only, eating, or drinking. Each observation was assumed to last $5 \mathrm{~min}$, which was the interval between observations. Chewing was considered as the summation of rumination and eating. The number of eating, lying, and chewing bouts, duration of each meal, total time eating, total time ruminating only, and total time chewing were calculated. Concurrently, feed left in the bunk of each cow was weighed at hourly intervals until $12 \mathrm{~h}$ after feeding, and then again at $24 \mathrm{~h}$ to determine eating rate over time and DMI. The DM contents of the diets offered and refused at $24 \mathrm{~h}$ of each cow were analyzed.

\section{Blood Sampling and Analysis}

Jugular venous blood was collected into $10 \mathrm{~mL}$ of lithium heparin and in 10-mL $\mathrm{K}_{2}$ EDTA evacuated tubes (Vacutainer, Becton Dickinson and Company, Franklin Lakes, NJ) on d 10 and 12 of each period at $1800 \mathrm{~h}$. Samples of whole blood from the lithium heparin tubes were analyzed within 2 min of collection for $\mathrm{pH}$, concentration of $\mathrm{HCO}_{3}{ }^{-}$, base excess, partial pressure of $\mathrm{CO}_{2}\left(\mathbf{p C O}_{2}\right)$, total dissolved $\mathrm{CO}_{2}\left(\mathbf{t} \mathbf{C O}_{\mathbf{2}}\right)$, partial pressure of $\mathrm{O}_{2}$, oxygen saturation, concentrations of $\mathrm{Na}$, $\mathrm{K}$, and ionized Ca (iCa), hemoglobin, hematocrit, and concentration of glucose using a handheld biochemical analyzer (VetScan i-STAT, Abaxis, Union City, CA). Blood tubes were placed on ice and centrifuged within $30 \mathrm{~min}$ of collection at $2,500 \times \mathrm{g}$ for $15 \mathrm{~min}$ at $7^{\circ} \mathrm{C}$ for plasma separation. Plasma samples were transferred to microtubes and stored frozen at $-20^{\circ} \mathrm{C}$ until analysis.

Plasma samples from tubes with lithium heparin were used for analyses of concentration of $\mathrm{Cl}$ and those from tubes with $\mathrm{K}_{2}$ EDTA were used for analyses of free fatty acids, insulin, and IGF1. Concentration of $\mathrm{Cl}$ in plasma was analyzed by a chemistry analyzer (RX Daytona $^{+}$; Randox Laboratories Ltd., Crumlin, UK) in a single assay, and the assay coefficient of variation averaged $1.3 \%$. Concentration of free fatty acids in plasma was analyzed by a chemistry analyzer (RX Daytona $^{+}$; Randox Laboratories Ltd.) in a single assay, and the resulting values were low, less than $0.10 \mathrm{mM}$, and the assay CV averaged $15.9 \%$. Concentration of insulin (Mercodia Bovine Insulin ELISA, Mercodia Inc., Uppsala, Sweden) and IGF1 in plasma (R\&D Systems Inc., Minneapolis, MN) were analyzed by enzyme immune assays. The intra- and interassay coefficients of variation were, respectively, 5.1 and $2.8 \%$ for insulin, and 6.6 and $3.5 \%$ for IGF1. Results from d 10 and 12 of each cow within period were averaged into a single mean for statistical analyses. The anion gap of blood was calculated using the equation $\left[\left(\mathrm{m} M\right.\right.$ of $\mathrm{Na}^{+}+\mathrm{m} M$ of $\left.\mathrm{K}^{+}\right)-\left(\mathrm{m} M\right.$ of $\mathrm{Cl}^{-}+\mathrm{m} M$ of $\left.\left.\mathrm{HCO}_{3}^{-}\right)\right]$.

\section{Urine Collection and Analyses of $\mathrm{pH}$, Creatinine, and Minerals}

Spot urine samples were collected twice daily, immediately before the morning feeding and $10 \mathrm{~h}$ later, from d 8 to 12 of each period. The perineal area was massaged until a clean and copious stream of urine was obtained, and $\mathrm{pH}$ was measured immediately using a pH meter (Accumet AE150, Fisher Scientific, Suwanee, GA). Samples were then stored at $-20^{\circ} \mathrm{C}$ for later analyses. Urine samples were thawed, composited by cow within morning and afternoon samples, and analyzed for concentrations of creatinine (RX Daytona ${ }^{+}$; Randox Laboratories Ltd.), total $\mathrm{Ca}, \mathrm{K}$, and $\mathrm{Na}$ by atomic absorption (AAnalyst 200; Perkin-Elmer Inc.); Cl by a chemistry analyzer (RX Daytona ${ }^{+}$; Randox Laboratories Ltd.); and S using an automated quantitative combustion digestion method (Elementar Analysensysteme, Elementar Americas Inc., Mt. Laurel, NJ).

Concentrations of creatinine, $\mathrm{Ca}, \mathrm{K}, \mathrm{Na}$, and $\mathrm{S}$ in urine were each analyzed in a single assay in duplicates and the coefficient of variation averaged $1.2 \%$ for creatinine, $3.1 \%$ for $\mathrm{Ca}, 2.8 \%$ for $\mathrm{Na}, 1.7 \%$ for $\mathrm{K}$, and $3.6 \%$ for S. Daily urinary creatinine excretion was calculated based on each animal BW in each period assuming that daily urinary creatinine was $25.2 \mathrm{mg} / \mathrm{kg}$ of BW according to data of growing Holstein heifers from Chizzotti et al. (2008). The choice for $25.2 \mathrm{mg}$ of creatinine excreted per $\mathrm{kg}$ of BW was based on the best estimate from Chizzotti et al. (2008) given that the mean BW for heifers in the experiment was $585 \mathrm{~kg}$. The methodology to estimate urinary volume and urinary mineral excretion has been validated by others (Tebbe and Weiss, 2018). Urinary minerals excretions were calculated based on the individual daily concentrations multiplied by daily urine volume. The strong ion difference (SID) in the urine was calculated as number of equivalents (Eq) of strong ions excreted in the urine per day according to the formula: $\mathrm{SID}=\left[\left(\mathrm{Eq}\right.\right.$ of $\mathrm{Na}^{+}+\mathrm{Eq}$ of $\left.\mathrm{K}^{+}\right)-(\mathrm{Eq}$ of $\mathrm{Cl}^{-}+\mathrm{Eq}$ of $\left.\left.\mathrm{S}^{2-}\right)\right] \times \mathrm{L}$ of urine to estimate the total $\mathrm{Eq} / \mathrm{d}$. 


\section{Statistical Analyses}

Data collected on d 8 to 14 of each period were averaged into a single mean per cow within a period for statistical analysis. Feeding behavior data and urine $\mathrm{pH}$ were analyzed as repeated measures within experimental unit.

All continuous data were evaluated for the distribution of the residuals and homogeneity of variance after model fitting. Data with deviations from normality were subjected to power transformation before subsequent analyses according to the Box-Cox method (Box and Cox, 1964) using the TRANSREG procedure of SAS (SAS/STAT version 9.4, SAS Institute Inc., Cary, NC). The LSM and SE of transformed data were back transformed for presentation according to Jørgensen and Pedersen (1998).

Data were analyzed by the MIXED procedure of SAS version 9.4 (SAS Institute Inc.) using the following model:

$$
\begin{aligned}
Y_{i j k l}=\mu & +T_{i}+P_{j}+S_{k}+T_{i} \times P_{j}+T_{i} \times S_{k} \\
& +P_{j} \times S_{k}+C(S)_{l k}+e_{i j k l},
\end{aligned}
$$

where $Y_{i j k l}$ is the dependent variable, $\mu$ is the overall mean, $T_{i}$ is the fixed effect of treatment $(i=1$ to 5$), P_{j}$ is the fixed effect of period ( $j=1$ to 5$), S_{k}$ is the fixed effect of square ( $k=1$ to 2$), T_{i} \times P_{j}$ is the interaction between $T_{i}$ and $P_{j}, T_{i} \times S_{k}$ is the interaction between $T_{i}$ and $S_{k}, P_{j} \times S_{k}$ is the interaction between $P_{j}$ and $S_{k}$, $C(S)_{l k}$ is the random effect of cow $(l=1$ to 10$)$ nested within square ( $k=1$ to 2$)$, and $e_{i j k l}$ is the random residual.

The Kenward-Roger method was used to calculate the approximate denominator degrees of freedom for the $\mathrm{F}$ tests in the mixed models. For data analyzed as repeated measures within cow in a given period such as urine $\mathrm{pH}$, respiration rate, and feeding behavior, models also included the fixed effect of time and the interaction between treatment and time, and the random effect of cow nested within treatment. The covariance structure was modeled based on fit statistics using the smallest corrected Akaike's information criterion.

In all analyses, single degrees of freedom contrasts of interest included the effect of adding acidogenic product (T1 vs. T4); the effect of acid-base status, alkalogenic versus acidogenic diets $(\mathrm{T} 2+\mathrm{T} 3$ vs. T4 $+\mathrm{T} 5$ ); the effect of adding salts containing $\mathrm{Cl}$ to an alkalogenic diet (T1 vs. T2); and the effect of adding salts containing $\mathrm{Cl}$ to an acidogenic diet (T4 vs. T5). Data are reported as least squares means and standard error of the difference.
The REG procedure of SAS (SAS/STAT version 9.4) was used to evaluate the relationships between blood $\mathrm{pH}$ and DMI or intake of minerals and urinary excretion of minerals. Statistical significance was considered at $P \leq 0.05$, and a tendency was considered at $0.05<$ $P \leq 0.10$.

\section{RESULTS}

All 10 cows completed the replicated $5 \times 5$ Latin square and contributed with data for statistical analyses with no missing values for any of the responses in any of the 5 periods.

\section{DMI and Feeding Behavior}

Treatment affected $(P<0.01)$ DMI of cows (Table $3)$. Feeding the acidogenic product reduced $(P=0.02)$ DMI by $0.6 \mathrm{~kg} / \mathrm{d}$ or $5.9 \%$. The decline in intake with feeding the acidogenic product was caused by changes in acid-base status because cows fed T2 and T3 consumed $0.6 \mathrm{~kg} / \mathrm{d}$ more $(P=0.003)$ DM than cows fed $\mathrm{T} 4$ and $\mathrm{T} 5$. Incorporating salts containing $\mathrm{Cl}$ to an alkalogenic or an acidogenic diet did not affect DMI of dry pregnant cows. Intake of DM as a percentage of BW followed the same pattern as that for DMI (Table $3)$. Feeding the acidogenic product reduced $(P=0.03)$ DMI as a percentage of BW, and the reduction was caused by the changes in acid-base balance. Cows fed T2 and T3 ate more $(P=0.003) \mathrm{DM}$ as a percentage of BW than those fed T4 and T5. Adding salts containing $\mathrm{Cl}$ to an alkalogenic or an acidogenic diet did not affect DMI as a percentage of BW. A linear relationship $(P=0.006)$ was observed between blood $\mathrm{pH}$ and DMI (Figure 1).

Feeding the acidogenic product did not affect $(P$ $=0.21)$ water intake; however, incorporating salts containing $\mathrm{Cl}$ to an alkalogenic or acidogenic diet increased water intake $(P<0.01$; Table 3$)$. In cows fed the alkalogenic diet, supplementing salts containing $\mathrm{Cl}$ increased water intake by $5.6 \mathrm{~L} / \mathrm{d}$ or $22 \%$. In cows fed the acidogenic diet, supplementing salts containing $\mathrm{Cl}$ increased water intake by $5.8 \mathrm{~L} / \mathrm{d}$ or $21.8 \%$.

Treatment tended $(P=0.10)$ to affect BW of cows (Table 3$)$. Cows fed T4 were $3.7 \mathrm{~kg}$ lighter $(P=0.03)$ than cows fed T1. Acid-base balance did not affect BW. Incorporating salts containing $\mathrm{Cl}$ to an alkalogenic diet did not affect BW, but incorporating the same salts to an acidogenic diet increased $(P<0.02) \mathrm{BW}$; cows fed T5 were $4.7 \mathrm{~kg}$ heavier than those fed T4. Feeding the acidogenic product or changes in acid-base balance did not affect average daily gain; however, incorporating 


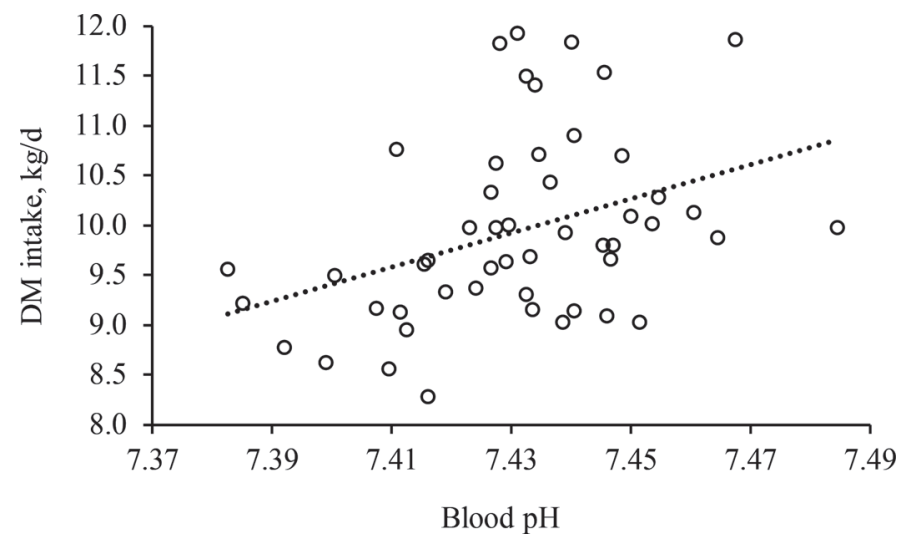

Figure 1. Relationship between blood $\mathrm{pH}$ and DMI in pregnant dry cows. A significant linear relationship was observed between blood $\mathrm{pH}$ and intake. Dry matter intake, $\mathrm{kg} / \mathrm{d}=-116.74345+17.04721 \times$ blood $\mathrm{pH}\left(\mathrm{R}^{2}=0.15 ; P=0.006\right)$.

salts containing $\mathrm{Cl}$ to an acidogenic diet tended $(P=$ $0.07)$ to increase daily $\mathrm{BW}$ gain. The increased $\mathrm{BW}$ gain in cows fed $\mathrm{T} 5$ resulted in improved feed efficiency with reduced $(P=0.04)$ DMI per unit of BW gain in those cows compared with cows fed T4.

As anticipated, intake of strong ions differed with treatments and reflected the dietary manipulations implemented and the DMI of cows. Intakes of $\mathrm{K}$ and $\mathrm{Na}$ decreased $(P<0.001)$ with feeding the acidogenic diets, but increased $(P<0.001)$ with supplementation of salts containing $\mathrm{Cl}$ to the alkalogenic or the acidogenic diet (Table 3). Intake of $\mathrm{Cl}$ increased $(P<0.001)$ with feeding the acidogenic product and by incorporating salts containing $\mathrm{Cl}$ to the alkalogenic or the acidogenic diet, whereas intake of $\mathrm{S}$ increased $(P<0.001)$ only in diets supplemented with the acidogenic product. Because of the treatments implemented, the intake of net Eq of strong ions averaged $2.0 \mathrm{Eq} / \mathrm{d}$ in cows fed T1, $\mathrm{T} 2$, and $\mathrm{T} 3$ (2.0 Eq/d more cations than anions), but averaged $-1.2 \mathrm{Eq} / \mathrm{d}$ in cows fed T4 and T5 $(1.2 \mathrm{Eq} / \mathrm{d}$ more anions than cations).

Time spent eating tended $(P=0.07)$ to be shorter in cows supplemented with the acidogenic product, but the effect did not seem to be mediated by acid-base balance (Table 4). Incorporating salts containing $\mathrm{Cl}$ to an acidogenic diet increased $(P=0.01)$ time spent eating by $10.2 \mathrm{~min} / 12 \mathrm{~h}$, or $8.3 \%$. Treatment did not affect time spent ruminating, chewing, drinking, or lying. Cows fed the acidogenic product had fewer $(P=$ 0.01 ) eating bouts because changes in acid-base balance that induces metabolic acidosis reduced $(P=0.01)$ eating bouts by $10.5 \%(\mathrm{~T} 2+\mathrm{T} 3=6.7$ vs. $\mathrm{T} 4+\mathrm{T} 5=$ 6.0 bouts/12 h). Treatment did not affect the number of rumination bouts, but altering the acid-base status by inducing metabolic acidosis reduced $(P=0.02)$ the number of chewing bouts in dairy cows $(\mathrm{T} 2+\mathrm{T} 3=$ 14.6 vs. $\mathrm{T} 4+\mathrm{T} 5=13.5$ bouts $/ 12 \mathrm{~h}$ ). Meal duration $(\mathrm{T} 2+\mathrm{T} 3=19.8$ vs. $\mathrm{T} 4+\mathrm{T} 5=22.0 \mathrm{~min} / \mathrm{meal})$ and intermeal interval $(\mathrm{T} 2+\mathrm{T} 3=92.0$ vs. $\mathrm{T} 4+\mathrm{T} 5=$ $107.8 \mathrm{~min})$ were longer $(P<0.01)$ in cows induced to have metabolic acidosis. Meal size tended $(P=0.07)$

Table 3. Effect of manipulating the DCAD and inclusion of chloride salts on performance in dry pregnant cows

\begin{tabular}{|c|c|c|c|c|c|c|c|c|c|c|c|}
\hline \multirow[b]{2}{*}{ Item } & \multicolumn{5}{|c|}{ Treatment $^{1}$} & \multirow[b]{2}{*}{$\mathrm{SE}$} & \multicolumn{5}{|c|}{$P$-value ${ }^{2}$} \\
\hline & $\mathrm{T} 1$ & $\mathrm{~T} 2$ & T3 & $\mathrm{T} 4$ & $\mathrm{~T} 5$ & & TRT & $\mathrm{AP}$ & $\mathrm{AB}$ & ClAlk & $\mathrm{ClAc}$ \\
\hline DMI, $\%$ of BW & 1.76 & 1.75 & 1.74 & 1.68 & 1.64 & 0.03 & 0.01 & 0.03 & 0.003 & 0.63 & 0.14 \\
\hline Water intake, L/d & 25.4 & 31.0 & 30.5 & 26.5 & 32.3 & 0.8 & $<0.001$ & 0.21 & 0.05 & $<0.001$ & $<0.001$ \\
\hline $\mathrm{BW}, \mathrm{kg}$ & 585.4 & 584.2 & 585.5 & 581.7 & 585.9 & 1.5 & 0.10 & 0.03 & 0.34 & 0.43 & 0.02 \\
\hline $\mathrm{ADG}, \mathrm{kg} / \mathrm{d}$ & 1.41 & 1.50 & 1.48 & 1.22 & 1.67 & 0.22 & 0.40 & 0.39 & 0.77 & 0.70 & 0.07 \\
\hline \multicolumn{12}{|l|}{ Intake, $\mathrm{g} / \mathrm{d}$} \\
\hline $\mathrm{K}$ & 146.0 & 186.8 & 174.2 & 125.6 & 170.3 & 2.9 & $<0.001$ & $<0.001$ & $<0.001$ & $<0.001$ & $<0.001$ \\
\hline $\mathrm{Na}$ & 4.1 & 42.4 & 55.2 & 12.9 & 50.6 & 1.0 & $<0.001$ & $<0.001$ & $<0.001$ & $<0.001$ & $<0.001$ \\
\hline $\mathrm{Cl}$ & 26.8 & 124.8 & 91.3 & 89.0 & 193.8 & 2.7 & $<0.001$ & $<0.001$ & $<0.001$ & $<0.001$ & $<0.001$ \\
\hline $\mathrm{S}$ & 18.5 & 18.2 & 37.4 & 38.2 & 38.0 & 0.6 & $<0.001$ & $<0.001$ & $<0.001$ & 0.63 & 0.79 \\
\hline $\mathrm{DCAD},{ }^{3}$ net $\mathrm{Eq} / \mathrm{d}$ & 2.01 & 1.98 & 1.96 & -1.11 & -1.27 & 0.06 & $<0.001$ & $<0.001$ & $<0.001$ & 0.61 & 0.03 \\
\hline
\end{tabular}

${ }^{1}$ Pregnant nulliparous Holstein cows were fed diets that differed in DCAD and supplemented with salts containing Cl when fed alkalogenic or acidogenic diets. T1 = diet with DCAD of $+196 \mathrm{mEq} / \mathrm{kg}$ of DM without addition of salts containing Cl; T2 = diet with DCAD of $+194 \mathrm{mEq} / \mathrm{kg}$ of DM with addition of $\mathrm{NaCl}$ and $\mathrm{KCl}$; T3 = diet with DCAD of $+192 \mathrm{mEq} / \mathrm{kg}$ of DM with addition of acidogenic product and $\mathrm{Na}_{3} \mathrm{H}\left(\mathrm{CO}_{3}\right)_{2} \cdot 2 \mathrm{H}_{2} \mathrm{O}$ and $\mathrm{K}_{2} \mathrm{CO}_{3} ; \mathrm{T} 4=$ diet with DCAD of $-114 \mathrm{mEq} / \mathrm{kg}$ of DM with addition of acidogenic product; T5 = diet with DCAD of $-113 \mathrm{mEq} / \mathrm{kg}$ with addition of acidogenic product, $\mathrm{NaCl}$, and $\mathrm{KCl}$.

${ }^{2} \mathrm{TRT}=$ effect of treatment from the ANOVA; AP = contrast of effect of adding acidogenic product $(\mathrm{T} 1 \mathrm{vs} . \mathrm{T} 4) ; \mathrm{AB}=$ contrast of acid-base status, alkalogenic vs. acidogenic diets ( $2+\mathrm{T} 3$ vs. $\mathrm{T} 4+\mathrm{T} 5)$; ClAlk = contrast of adding salts containing $\mathrm{Cl}$ to an alkalogenic diet (T1 vs. $\mathrm{T} 2) ; \mathrm{ClAc}=$ contrast of adding salts containing $\mathrm{Cl}$ to an acidogenic diet (T4 vs. T5).

${ }^{3}$ Intake of net equivalents (Eq) considered the DCAD of the diet offered and the DMI (e.g., a cow fed a diet with $-114 \mathrm{mEq} / \mathrm{kg}$ and DMI of 10 $\mathrm{kg} / \mathrm{d}$ would result in a net Eq intake of $-1.14 \mathrm{Eq} / \mathrm{d}$, indicating that this cow consumed 1.14 more Eq of anions than cations). 
Table 4. Effect of manipulating the DCAD and inclusion of chloride salts on feeding behavior in dry pregnant cows

\begin{tabular}{|c|c|c|c|c|c|c|c|c|c|c|c|}
\hline Item & \multicolumn{5}{|c|}{ Treatment $^{1}$} & $\mathrm{SE}$ & \multicolumn{5}{|c|}{$P$-value ${ }^{2}$} \\
\hline DMI, $\mathrm{kg} / 12 \mathrm{~h}$ & 7.2 & 7.3 & 7.7 & 7.0 & 7.1 & 0.4 & 0.52 & 0.76 & 0.19 & 0.78 & 0.81 \\
\hline Standing & 40.5 & 35.5 & 39.0 & 43.0 & 46.8 & 8.7 & 0.78 & 0.79 & 0.27 & 0.60 & 0.69 \\
\hline Lying & 163.0 & 167.8 & 156.0 & 165.8 & 159.3 & 9.7 & 0.87 & 0.83 & 0.94 & 0.71 & 0.61 \\
\hline Drinking, $\min / 12 \mathrm{~h}$ & 9.8 & 9.8 & 11.5 & 10.5 & 12.5 & 2.1 & 0.84 & 0.80 & 0.67 & 0.99 & 0.49 \\
\hline Lying, min/12 h & 434.8 & 448.5 & 433.0 & 434.0 & 423.0 & 18.3 & 0.89 & 0.98 & 0.51 & 0.60 & 0.67 \\
\hline \multicolumn{12}{|l|}{ Bouts, no./12 h } \\
\hline Eating & 6.8 & 6.3 & 7.1 & 5.8 & 6.1 & 0.4 & 0.02 & 0.01 & 0.01 & 0.16 & 0.32 \\
\hline Rumination & 7.8 & 8.2 & 7.6 & 7.6 & 7.5 & 0.3 & 0.53 & 0.66 & 0.32 & 0.39 & 0.82 \\
\hline Chewing & 14.6 & 14.5 & 14.7 & 13.4 & 13.6 & 0.5 & 0.09 & 0.04 & 0.02 & 0.85 & 0.64 \\
\hline Meal duration, min/meal & 19.3 & 20.6 & 18.9 & 21.7 & 22.3 & 0.6 & 0.02 & 0.03 & 0.009 & 0.20 & 0.54 \\
\hline
\end{tabular}

${ }^{1}$ Pregnant nulliparous Holstein cows were fed diets that differed in DCAD and supplemented with salts containing Cl when fed alkalogenic or acidogenic diets. T1 = diet with DCAD of $+196 \mathrm{mEq} / \mathrm{kg}$ of DM without addition of salts containing $\mathrm{Cl}$; T2 $=$ diet with DCAD of $+194 \mathrm{mEq} / \mathrm{kg}$ of DM with addition of $\mathrm{NaCl}$ and $\mathrm{KCl}$; T3 = diet with DCAD of $+192 \mathrm{mEq} / \mathrm{kg}$ of DM with addition of acidogenic product and $\left.\mathrm{Na}_{3} \mathrm{H}_{(\mathrm{CO}}\right)_{2} \cdot 2 \mathrm{H}_{2} \mathrm{O}$ and $\mathrm{K}_{2} \mathrm{CO}_{3} ; \mathrm{T} 4=$ diet with DCAD of $-114 \mathrm{mEq} / \mathrm{kg}$ of DM with addition of acidogenic product; T5 = diet with DCAD of $-113 \mathrm{mEq} / \mathrm{kg}$ with addition of acidogenic product, $\mathrm{NaCl}$, and $\mathrm{KCl}$.

${ }^{2} \mathrm{TRT}=$ effect of treatment from the ANOVA; $\mathrm{AP}=$ contrast of effect of adding acidogenic product (T1 vs. T4); $\mathrm{AB}=$ contrast of acid-base status, alkalogenic vs. acidogenic diets (T2 + T3 vs. T4 + T5); ClAlk = contrast of adding salts containing $\mathrm{Cl}$ to an alkalogenic diet (T1 vs. $\mathrm{T} 2) ; \mathrm{ClAc}=$ contrast of adding salts containing $\mathrm{Cl}$ to an acidogenic diet (T4 vs. T5).

to be larger in cows affected by feeding the acidogenic product, but this effect did not seem to be mediated by changes in acid-base balance. Supplementing salts containing $\mathrm{Cl}$ to an alkalogenic or an acidogenic diet did not affect chewing bouts, meal duration or size, or intermeal interval (Table 4). Treatment did not affect eating rate. The pattern of DMI after feeding was influenced by $(P<0.001)$ hour relative to feeding, but did not differ $(P=0.93)$ with treatments. Cows consumed almost $25 \%$ of the total daily DMI in the first hour after feeding, after which it dropped to 3 to $7 \%$ per hour of the total DM consumed in $12 \mathrm{~h}$. The hourly rates of intake in the first $12 \mathrm{~h}$ after feeding averaged 5.94, 6.02, $6.29,5.93$, and $5.96( \pm 0.3) \% /$ hour for treatments 1 to 5 , respectively.

\section{Blood Acid-Base Status and Concentrations of Metabolites}

Supplementing the acidogenic product reduced $(P<$ 0.001 ) blood $\mathrm{pH}$ by $0.03 \mathrm{pH}$ units, which was sufficient to reduce $(P<0.01)$ blood $\mathrm{HCO}_{3}{ }^{-}$, base excess, and $\mathrm{tCO}_{2}$, compensatory changes that help the cow adjust to the induced metabolic acidosis (Table 5). The observed differences with feeding the acidogenic product were all mediated by changes in acid-base status based on the contrast of $\mathrm{T} 2+\mathrm{T} 3$ compared with $\mathrm{T} 4+\mathrm{T} 5$ (Table 5). For instance, blood pH was 0.018 units less
$(P<0.001)$ and $\mathrm{HCO}_{3}{ }^{-}$had $1.65 \mathrm{mM}$ smaller $(P<$ $0.001)$ concentration in cows fed T4 and T5 compared with those fed T2 and T3. Addition of salts containing $\mathrm{Cl}$ to an alkalogenic or to an acidogenic diet had minor effects on measures of acid-base balance or blood gases in cows.

Treatments affected $(P<0.05)$ concentrations of $\mathrm{Na}$, $\mathrm{K}$, and $\mathrm{Cl}$ in blood of cows (Table 5). Concentrations of $\mathrm{Na}$ were smallest for cows fed $\mathrm{T} 1$ than all other diets. Adding salts containing $\mathrm{Cl}$ increased $(P=0.01)$ blood $\mathrm{Na}$ in cows fed the alkalogenic diet, but not in those fed the acidogenic diet. Concentrations of $\mathrm{K}$ and $\mathrm{Cl}$ in blood were smallest for cows fed $\mathrm{T} 1$ than the other treatments. Altering the acid-base status of cows by feeding acidogenic diets as T4 and T5 increased $(P<$ 0.01) concentrations of $\mathrm{K}$ and $\mathrm{Cl}$ in blood compared with feeding alkalogenic diets as T2 and T3. Supplementing salts containing $\mathrm{Cl}$ to an alkalogenic diet increased $(P<0.01)$ concentrations of $\mathrm{Na}$ and $\mathrm{K}$ in blood and tended $(P=0.09)$ to increase concentrations of $\mathrm{Cl}$ in blood (Table 5), whereas supplementing salts containing $\mathrm{Cl}$ to an acidogenic diet increased $(P=0.01)$ concentrations of only $\mathrm{Cl}$ in blood. Despite the changes in blood minerals with the different diets, treatment did not affect the anion gap of blood. The concentrations of $\mathrm{iCa}$ in blood were not affected by the acidogenic product or by dietary changes aimed to alter acid-base status, but they increased $(P<0.05)$ with addition of 
salts containing $\mathrm{Cl}$ to an alkalogenic or acidogenic diet, although increments were of small magnitude. Treatment did not affect hematocrit or hemoglobin content of blood.

Dietary treatments had minor effects on blood concentrations of glucose, free fatty acids, IGF1, and insulin (Table 5). Feeding the acidogenic product or manipulating the acid-base status tended $(P=0.07)$ to reduce blood glucose concentration. Concentration of free fatty acids in plasma tended $(P=0.08)$ to be less for cows fed T3 compared with T1, although neither supplementing the acidogenic product nor altering the acid-base status of cows by diets affected concentrations of IGF1 or insulin. Supplementing salts containing $\mathrm{Cl}$ to an acidogenic or alkalogenic diet increased $(P$ $<0.05)$ only concentrations of IGF1, but had no effects on those of glucose, free fatty acids, or insulin.

\section{Urinary Excretion of Minerals and Strong Ion Difference}

Feeding the acidogenic product and altering the acidbase balance of cows by feeding $\mathrm{T} 4$ and $\mathrm{T} 5$ reduced
$(P<0.001)$ urinary $\mathrm{pH}$ (Table 6$)$. Incorporating salts containing $\mathrm{Cl}$ to an alkalogenic diet decreased $(P=$ 0.01 ) urinary $\mathrm{pH}$ by 0.26 units, whereas incorporating salts containing $\mathrm{Cl}$ to an acidogenic diet did not affect urinary $\mathrm{pH}$ in dry pregnant cows. The $\mathrm{pH}$ of urine did not differ $(P=0.66)$ between morning and afternoon collections (Table 6).

Urinary volume increased $(P<0.001)$ with supplementation of $\mathrm{Cl}$ salts to diets (Table 6). Cows fed T2 excreted $4.5 \mathrm{~L}$ more $(P<0.001)$ than those fed T1, and cows fed T5 excreted 5.3 L more $(P<0.001)$ urine than cows fed T4. Feeding the acidogenic product did not affect urinary volume. Urinary excretion of $\mathrm{Na}$ and $\mathrm{K}$ decreased $(P<0.001)$ with feeding acidogenic diets in T4 and T5 compared with $\mathrm{T} 2$ and $\mathrm{T} 3$, whereas excretion of $\mathrm{Cl}$ increased $(P<0.001)$ with the same dietary manipulations. Feeding salts containing $\mathrm{Cl}$ to an alkalogenic or acidogenic diet increased $(P$ $<0.001$ ) urinary excretion of $\mathrm{Na}, \mathrm{Cl}$, and $\mathrm{K}$. Urinary excretion of $\mathrm{S}$ increased with increased $(P<0.001)$ intake of $\mathrm{S}$ from feeding the acidogenic product regardless of changes in acid-base balance. Excretion of $\mathrm{Ca}$ in urine was influenced $(P<0.001)$ only by changes

Table 5. Effect of manipulating the DCAD and inclusion of chloride salts on blood gases, electrolytes, and acid-base measures in dry pregnant cows

\begin{tabular}{|c|c|c|c|c|c|c|c|c|c|c|c|}
\hline \multirow[b]{2}{*}{ Item } & \multicolumn{5}{|c|}{ Treatment $^{1}$} & \multirow[b]{2}{*}{$\mathrm{SE}$} & \multicolumn{5}{|c|}{$P$-value ${ }^{2}$} \\
\hline & $\mathrm{T} 1$ & $\mathrm{~T} 2$ & $\mathrm{~T} 3$ & $\mathrm{~T} 4$ & T5 & & TRT & $\mathrm{AP}$ & $\mathrm{AB}$ & ClAlk & $\mathrm{ClAc}$ \\
\hline Base excess, $\mathrm{m} M$ & 1.85 & 1.20 & 1.45 & -0.20 & -0.95 & 0.32 & $<0.001$ & $<0.001$ & $<0.001$ & 0.13 & 0.09 \\
\hline $\mathrm{HCO}_{3}{ }^{-}, \mathrm{mM}$ & 25.9 & 25.5 & 25.8 & 24.3 & 23.7 & 0.3 & 0.001 & 0.003 & $<0.001$ & 0.36 & 0.14 \\
\hline $\mathrm{pCO}_{2},{ }^{3} \mathrm{~mm} \mathrm{Hg}$ & 37.4 & 38.2 & 38.4 & 37.0 & 36.6 & 0.7 & 0.13 & 0.61 & 0.02 & 0.26 & 0.62 \\
\hline Total $\mathrm{CO}_{2}, \mathrm{~m} M$ & 27.0 & 26.6 & 26.9 & 25.4 & 24.9 & 0.4 & 0.003 & 0.005 & $<0.001$ & 0.45 & 0.22 \\
\hline $\mathrm{Na}, \mathrm{m} M$ & 140.75 & 141.70 & 141.45 & 141.55 & 142.00 & 0.24 & 0.02 & 0.02 & 0.36 & 0.01 & 0.15 \\
\hline $\mathrm{K}, \mathrm{m} M$ & 3.84 & 4.03 & 4.02 & 4.11 & 4.20 & 0.05 & 0.002 & 0.001 & 0.01 & 0.009 & 0.15 \\
\hline $\mathrm{Cl}, \mathrm{m} M$ & 99.4 & 100.8 & 99.6 & 100.8 & 103.2 & 0.6 & 0.004 & 0.08 & 0.006 & 0.09 & 0.01 \\
\hline Anion gap, ${ }^{5} \mathrm{~m} M$ & 19.3 & 19.4 & 20.1 & 20.5 & 19.3 & 0.5 & 0.39 & 0.12 & 0.78 & 0.83 & 0.14 \\
\hline $\mathrm{iCa},{ }^{6} \mathrm{~m} M$ & 1.216 & 1.237 & 1.224 & 1.228 & 1.245 & 0.007 & 0.03 & 0.14 & 0.28 & 0.02 & 0.05 \\
\hline Hematocrit, \% & 28.2 & 28.0 & 27.3 & 27.6 & 27.5 & 0.5 & 0.11 & 0.11 & 0.71 & 0.46 & 0.66 \\
\hline Hemoglobin, g/dL & 9.60 & 9.51 & 9.31 & 9.41 & 9.36 & 0.18 & 0.13 & 0.11 & 0.75 & 0.42 & 0.65 \\
\hline
\end{tabular}

${ }^{1}$ Pregnant nulliparous Holstein cows were fed diets that differed in DCAD and supplemented with salts containing Cl when fed alkalogenic or acidogenic diets. T1 = diet with DCAD of $+196 \mathrm{mEq} / \mathrm{kg}$ of DM without addition of salts containing Cl; T2 = diet with DCAD of $+194 \mathrm{mEq} / \mathrm{kg}$ of DM with addition of $\mathrm{NaCl}$ and $\mathrm{KCl}$; T3 = diet with DCAD of $+192 \mathrm{mEq} / \mathrm{kg}$ of DM with addition of acidogenic product and $\mathrm{Na}_{3} \mathrm{H}\left(\mathrm{CO}_{3}\right)_{2} \cdot 2 \mathrm{H}_{2} \mathrm{O}$ and $\mathrm{K}_{2} \mathrm{CO}_{3}$; T4 = diet with DCAD of $-114 \mathrm{mEq} / \mathrm{kg}$ of DM with addition of acidogenic product; T5 = diet with DCAD of $-113 \mathrm{mEq} / \mathrm{kg}$ with addition of acidogenic product, $\mathrm{NaCl}$, and $\mathrm{KCl}$.

${ }^{2} \mathrm{TRT}=$ effect of treatment from the ANOVA; AP = contrast of effect of adding acidogenic product (T1 vs. T4); AB = contrast of acid-base status, alkalogenic vs. acidogenic diets $(\mathrm{T} 2+\mathrm{T} 3$ vs. T4 $+\mathrm{T} 5)$; ClAlk $=$ contrast of adding salts containing $\mathrm{Cl}$ to an alkalogenic diet (T1 vs $\mathrm{T} 2) ; \mathrm{ClAc}=$ contrast of adding salts containing $\mathrm{Cl}$ to an acidogenic diet (T4 vs. T5).

${ }^{3} \mathrm{pCO}_{2}=$ partial pressure of $\mathrm{CO}_{2}$.

${ }^{4} \mathrm{pO}_{2}=$ partial pressure of $\mathrm{O}_{2}$.

${ }^{5}$ Anion gap calculated using the equation $\left[\left(\mathrm{m} M\right.\right.$ of $\mathrm{Na}^{+}+\mathrm{m} M$ of $\left.\mathrm{K}^{+}\right)-\left(\mathrm{m} M\right.$ of $\mathrm{Cl}^{-}+\mathrm{m} M$ of $\left.\left.\mathrm{HCO}_{3}^{-}\right)\right]$.

${ }^{6} \mathrm{iCa}=$ ionized calcium 
Table 6. Effect of manipulating the DCAD and inclusion of chloride salts on urinary volume and excretion of minerals in dry pregnant cows

\begin{tabular}{|c|c|c|c|c|c|c|c|c|c|c|c|}
\hline Item & \multicolumn{5}{|c|}{ Treatment $^{1}$} & $\mathrm{SE}$ & \multicolumn{5}{|c|}{$P$-value ${ }^{2}$} \\
\hline \multicolumn{12}{|l|}{$\overline{\text { Urine } \mathrm{pH}^{3}}$} \\
\hline PM & 8.10 & 7.86 & 7.92 & 5.65 & 5.59 & & & & & & \\
\hline \multicolumn{12}{|l|}{ Urine } \\
\hline Creatinine, $\mathrm{m} M$ & 12.15 & 8.42 & 8.57 & 11.08 & 7.74 & 0.52 & $<0.001$ & 0.09 & 0.05 & $<0.001$ & $<0.001$ \\
\hline $\mathrm{Cl}, \mathrm{g} / \mathrm{d}$ & 32.6 & 106.6 & 76.8 & 84.6 & 164.8 & 5.6 & $<0.001$ & $<0.001$ & $<0.001$ & $<0.001$ & $<0.001$ \\
\hline $\mathrm{K}, \mathrm{g} / \mathrm{d}$ & 137.0 & 175.8 & 164.2 & 130.1 & 173.2 & 4.5 & $<0.001$ & 0.28 & 0.002 & $<0.001$ & $<0.001$ \\
\hline $\mathrm{S}, \mathrm{g} / \mathrm{d}$ & 7.22 & 8.85 & 21.85 & 22.37 & 22.77 & 0.92 & $<0.001$ & $<0.001$ & $<0.001$ & 0.22 & 0.99 \\
\hline $\mathrm{Ca}, \mathrm{g} / \mathrm{d}$ & 0.83 & 0.80 & 0.66 & 7.53 & 7.87 & 0.37 & $<0.001$ & $<0.001$ & $<0.001$ & 0.92 & 0.31 \\
\hline $\mathrm{SID},{ }^{4} \mathrm{Eq} / \mathrm{d}$ & 2.23 & 2.14 & 2.18 & -0.09 & -0.05 & 0.14 & $<0.001$ & $<0.001$ & $<0.001$ & 0.44 & 0.74 \\
\hline \multicolumn{12}{|l|}{ Respiration rate } \\
\hline $\mathrm{AM}$ & 27.1 & 26.9 & 26.3 & 27.4 & 28.1 & 0.40 & 0.007 & 0.14 & $<0.001$ & 0.60 & 0.27 \\
\hline
\end{tabular}

${ }^{1}$ Pregnant nulliparous Holstein cows were fed diets that differed in DCAD and supplemented with salts containing Cl when fed alkalogenic or acidogenic diets. T1 = diet with DCAD of $+196 \mathrm{mEq} / \mathrm{kg}$ of DM without addition of salts containing $\mathrm{Cl}$; T2 $=$ diet with $\mathrm{DCAD}$ of $+194 \mathrm{mEq} / \mathrm{kg}$ of DM with addition of $\mathrm{NaCl}$ and $\mathrm{KCl}$; T3 = diet with DCAD of $+192 \mathrm{mEq} / \mathrm{kg}$ of DM with addition of acidogenic product and $\mathrm{Na}_{3} \mathrm{H}\left(\mathrm{CO}_{3}\right)_{2} \cdot 2 \mathrm{H}_{2} \mathrm{O}$ and $\mathrm{K}_{2} \mathrm{CO}_{3} ; \mathrm{T} 4=$ diet with DCAD of $-114 \mathrm{mEq} / \mathrm{kg}$ of DM with addition of acidogenic product; T5 = diet with DCAD of $-113 \mathrm{mEq} / \mathrm{kg}$ with addition of acidogenic product, $\mathrm{NaCl}$, and $\mathrm{KCl}$.

${ }^{2} \mathrm{TRT}=$ effect of treatment from the ANOVA; $\mathrm{AP}=$ contrast of effect of adding acidogenic product $(\mathrm{T} 1 \mathrm{vs} . \mathrm{T} 4) ; \mathrm{AB}=$ contrast of acid-base status, alkalogenic vs. acidogenic diets ( $2+\mathrm{T} 3$ vs. T4 $+\mathrm{T} 5)$; ClAlk = contrast of adding salts containing $\mathrm{Cl}$ to an alkalogenic diet (T1 vs. $\mathrm{T} 2) ; \mathrm{ClAc}=$ contrast of adding salts containing $\mathrm{Cl}$ to an acidogenic diet (T4 vs. T5).

${ }^{3}$ Urine samples were collected and respiration rate measured immediately before the morning feeding (AM) and $10 \mathrm{~h}$ later (PM) on d 8 to 12 of each period. The $P$-values represent the effects of treatments on urine $\mathrm{pH}$ across the AM and $\mathrm{PM}$ measurements and no difference $(P=0.66)$ was observed between $\mathrm{pH}$ measured in the morning or afternoon.

${ }^{4} \mathrm{SID}=$ strong ion difference calculated as $\left[\left(\mathrm{Eq}\right.\right.$ of $\mathrm{Na}^{+}+\mathrm{Eq}$ of $\left.\mathrm{K}^{+}\right)-\left(\mathrm{Eq}\right.$ of $\mathrm{Cl}^{-}+\mathrm{Eq}$ of $\left.\left.\mathrm{S}^{2-}\right)\right]$ per day based on the estimated liters of urine produced daily.

in acid-base balance induced by feeding the acidogenic product. On the other hand, when cows were fed the acidogenic product, but also supplemented with buffers to avoid metabolic acidosis such as in diet T3, then urinary excretion of $\mathrm{Ca}$ remained the same compared with cows fed $\mathrm{T} 1$ or T2. The SID in Eq/d excreted in the urine did not change in diets $\mathrm{T} 1, \mathrm{~T} 2$, and $\mathrm{T} 3$; however, inducing a compensated metabolic acidosis by feeding the acidogenic product in T4 and T5 reduced $(P<0.001)$ the SID compared with cows fed T2 and $\mathrm{T} 3$ as a renal compensatory mechanism for metabolic acidosis. Urinary Ca excretion was not associated with intake of $\mathrm{Ca}$ (Figure 2A); however, urinary excretions of other minerals were all strongly related to intake of the respective minerals (Figure $2 \mathrm{~B}$ to $2 \mathrm{E}$ ), which resulted in 2 distinct clusters for urinary SID. The first cluster included treatments $\mathrm{T} 4$ and $\mathrm{T} 5$, the acidogenic diets, in which the urinary SID was close to 0 or even negative and the intake of net $\mathrm{Eq}$ was within 1 and $2 \mathrm{Eq} / \mathrm{d}$ more anions than cations. The second cluster included treatments $\mathrm{T} 1$ to $\mathrm{T} 3$, the alkalogenic diets in which the urinary SID was greater than $+1.0 \mathrm{Eq} / \mathrm{d}$ and the corresponding intake of net Eq of DCAD was greater than $1.8 \mathrm{Eq} / \mathrm{d}$ more cations than anions (Figure $2 \mathrm{~F})$.
Respiratory frequency increased in diets designed to induce a compensated metabolic acidosis $(\mathrm{T} 2+\mathrm{T} 3=$ 27.0 vs. $\mathrm{T} 4+\mathrm{T} 5=28.7 \pm 0.4 / \mathrm{min})$. Supplementing salts containing $\mathrm{Cl}$ did not affect respiration rate and respiratory frequency was greater $(P<0.001)$ in the afternoon than in the morning period.

\section{DISCUSSION}

The goal of the current experiment was to understand if changes in DMI induced by feeding acidogenic diets are caused by the supplementation of acidogenic products or by the alterations in acid-base balance resulting from the metabolic acidosis induced by diets with negative DCAD. A common finding in experiments in which cows are fed diets with a reduced DCAD is a depression in intake (Charbonneau et al., 2006; Santos et al., 2018; Lopera et al., 2018; Martinez et al., 2018a). Often, the reduced intake in prepartum cows fed diets with negative DCAD has been attributed to possible palatability issues associated with some of the salts used to supplement $\mathrm{Cl}$ or $\mathrm{S}$ as strong anions (Oetzel et al., 1988; Oetzel and Barmore, 1993) or a response to metabolic acidosis (Vagnoni and Oetzel, 1998). 
Feeding dry pregnant cows diets with negative DCAD depressed DMI $0.6 \mathrm{~kg} / \mathrm{d}$ or $5.9 \%$ and this depression was abolished when the diet including the acidogenic product also was supplemented with alkalogenic salts to prevent the metabolic acidosis and result in a DCAD similar to the diets without any acidogenic product. The reduction in DMI in cows fed acidogenic diets resulted in a decline in intake from 1.75 to $1.66 \%$ of BW. However, no difference was observed when salts containing $\mathrm{Cl}$ were incorporated to either an alkalogenic or to an acidogenic diet. Such results demonstrate that by only incorporating salts containing $\mathrm{Cl}$ to diets without changing the DCAD does not affect intake. Diets were initially designed to contain either 200 or $-100 \mathrm{mEq} / \mathrm{kg}$, a difference of $300 \mathrm{mEq} / \mathrm{kg}$ of DM. It was also anticipated that dry primigravid cows would consume approximately $10 \mathrm{~kg}$ of DM/d (NRC, 2001), which was expected to result in a differential intake of $3 \mathrm{Eq} / \mathrm{d}$ more anions than cations in those fed T4 and T5 than those fed T1 to T3. Such differential intake in Eq of anions has been shown to be associated with a depression in DMI in prepartum dairy cows (Charbonneau et al., 2006).

An important finding of the present experiment was that supplementation of sodium sesquicarbonate and potassium carbonate to the diet containing the acidogenic product (T3), which resulted in the same DCAD as $\mathrm{T} 1$ and $\mathrm{T} 2$, prevented the depression in DMI that was observed when only the acidogenic product was supplemented to the diet of cows fed T4. These results support the concept that inducing metabolic acidosis seems to be the underlying reason for the reduced DMI
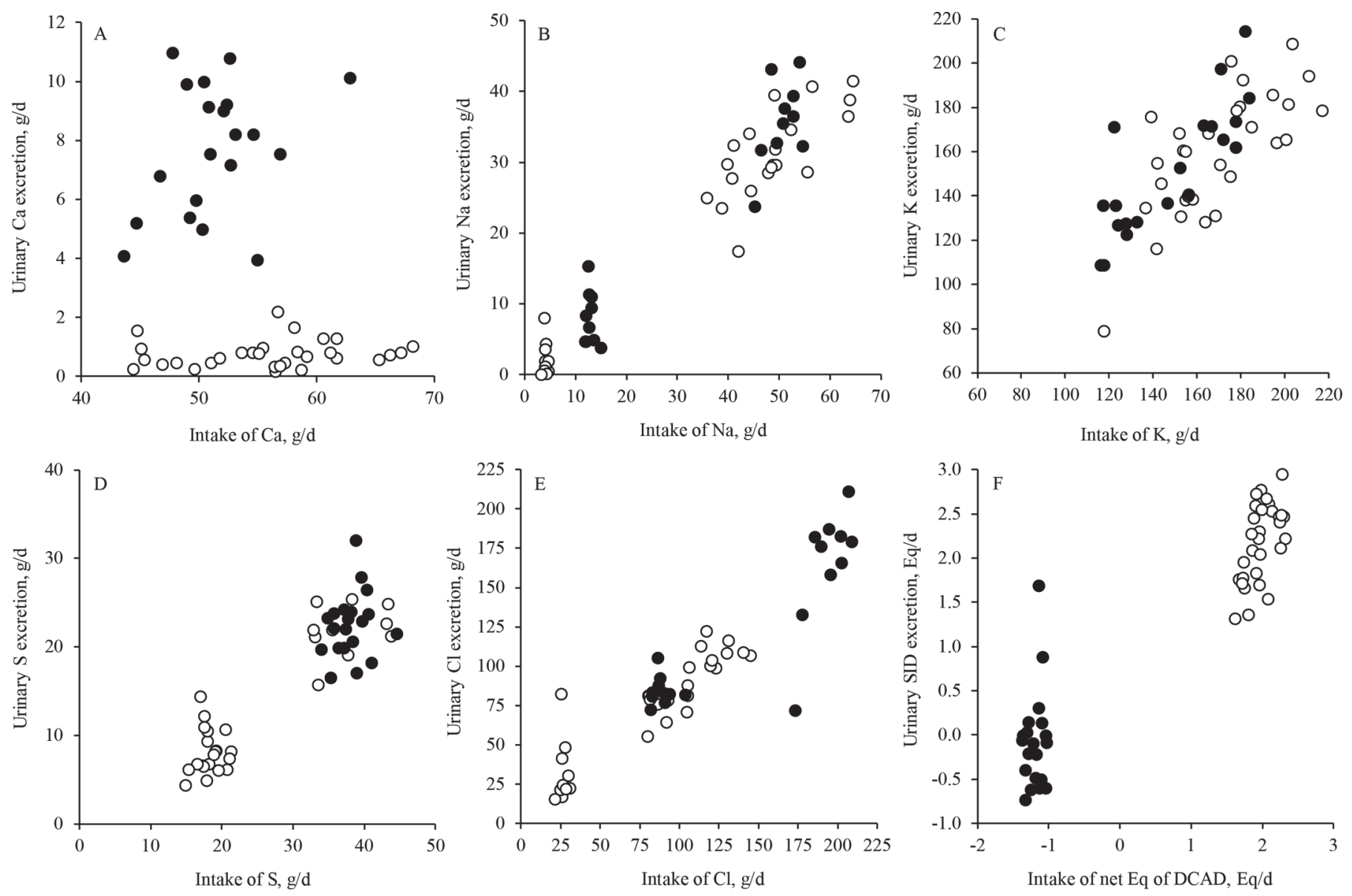

Figure 2. Relationship between intake and urinary excretion of minerals in cows fed alkalogenic diets (T1, T2, and T3; open circles, $\bigcirc)$ and cows fed acidogenic diets (T4 and T5; closed circles, $\bullet$ ). T1 = diet with DCAD of $+196 \mathrm{mEq} / \mathrm{kg}$ of DM without addition of salts containing Cl; $\mathrm{T} 2=$ diet with DCAD of $+194 \mathrm{mEq} / \mathrm{kg}$ of DM with addition of $\mathrm{NaCl}$ and $\mathrm{KCl}$; T3 = diet with DCAD of $+192 \mathrm{mEq} / \mathrm{kg}$ of DM with addition of acidogenic product and $\mathrm{Na}_{3} \mathrm{H}\left(\mathrm{CO}_{3}\right)_{2} \cdot 2 \mathrm{H}_{2} \mathrm{O}$ and $\mathrm{K}_{2} \mathrm{CO}_{3} ; \mathrm{T} 4=$ diet with DCAD of $-114 \mathrm{mEq} / \mathrm{kg}$ of DM with addition of acidogenic product; T5 $=$ diet with DCAD of $-113 \mathrm{mEq} / \mathrm{kg}$ with addition of acidogenic product, $\mathrm{NaCl}$, and $\mathrm{KCl}$. Panel $\mathrm{A}$, calcium; urinary Ca, $\mathrm{g} / \mathrm{d}=12.08-0.1579$ $\times \mathrm{Ca}$ intake $\mathrm{g} / \mathrm{d}\left(\mathrm{R}^{2}=0.05 ; P=0.06\right)$. Panel $\mathrm{B}$, sodium; urinary $\mathrm{Na}, \mathrm{g} / \mathrm{d}=-0.380+0.6674 \times \mathrm{Na}$ intake $\mathrm{g} / \mathrm{d}\left(\mathrm{R}^{2}=0.92 ; P<0.001\right) . \mathrm{Panel}$ $\mathrm{C}$, potassium; urinary $\mathrm{K}, \mathrm{g} / \mathrm{d}=29.03+0.7912 \times \mathrm{K}$ intake $\mathrm{g} / \mathrm{d}\left(\mathrm{R}^{2}=0.54 ; P<0.001\right)$. Panel $\mathrm{D}$, sulfur; urinary $\mathrm{S}, \mathrm{g} / \mathrm{d}=-4.073+0.6861 \times \mathrm{S}$ intake $\mathrm{g} / \mathrm{d}\left(\mathrm{R}^{2}=0.81 ; P<0.001\right)$. Panel $\mathrm{E}$, chlorine; urinary $\mathrm{Cl}, \mathrm{g} / \mathrm{d}=9.514+0.7949 \times \mathrm{Cl}$ intake $\mathrm{g} / \mathrm{d}\left(\mathrm{R}^{2}=0.85 ; P<0.001\right)$. Panel $\mathrm{F}$, strong ion difference; urinary SID, Eq/d = $0.7723+0.7166 \times \mathrm{DCAD}$ intake $\mathrm{Eq} / \mathrm{d}\left(\mathrm{R}^{2}=0.86 ; P<0.001\right)$. 
observed when cows are fed diets containing acidogenic products or salts (Charbonneau et al., 2006). In fact, a weak but significant linear relationship was observed between blood $\mathrm{pH}$ and DMI. As the blood $\mathrm{pH}$ decreased from 7.485 to 7.383 , the range of observed values in experimental cows, the estimated DMI decreased from approximately 10.9 to $9.1 \mathrm{~kg} / \mathrm{d}$, corroborating the finding that feeding acidogenic diets influences acid-base balance of cows that mediates the depression in DMI. One cannot discount that cows might select against some salts because of possible palatability issues (Oetzel and Barmore, 1993). The work of Oetzel and Barmore (1993) showed that concentrate intake decreased when grain mixes were supplemented with acidogenic salts, and that cows ate less concentrate when supplemented with ammonium chloride or calcium chloride than magnesium sulfate. Chloride is known to be more acidogenic than sulfates because of the increased bioavailability (Goff et al., 2004). Therefore, it is possible that differences in concentrate intake when cows were fed acidogenic products in a component fed system might have been mediated by changes in acid-base status and not just palatability. Feeding the same amount of Eq of anions resulted in more acidifying effect when originated from chloride than sulfate sources (Goff et al., 2004).

Feeding diets with negative DCAD typically induce a compensated metabolic acidosis (Vagnoni and Oetzel, 1998; Charbonneau et al., 2006; Rodney et al., 2018), which is characterized by a reduction in blood $\mathrm{pH}$, $\mathrm{HCO}_{3}{ }^{-}$, and $\mathrm{pCO}_{2}$ and an increased urinary acid excretion. Current results clearly showed similar acid-base responses as previously demonstrated and reinforce the findings that feeding diets with negative DCAD alter blood gases and the acid-base status of dry pregnant cows resulting in a compensated metabolic acidosis. Blood $\mathrm{pH}, \mathrm{HCO}_{3}^{-}$, base excess, and $\mathrm{pCO}_{2}$ and $\mathrm{tCO}_{2}$ were all reduced in cows fed $\mathrm{T} 4$ and $\mathrm{T} 5$ compared with cows fed the diets with positive DCAD in T1 to T3. Acidogenic diets promote an influx of anions systemically that leads to a loss of $\mathrm{HCO}_{3}{ }^{-}$from removal of $\mathrm{CO}_{2}$ and a concurrent increase in $\mathrm{H}^{+}$concentration to maintain electroneutrality. As consequence, the proton influx triggers a compensatory mechanism by increased respiratory frequency with hypocapnia caused by loss of $\mathrm{CO}_{2}$, mobilization of bicarbonate and carbonate from skeletal reserves for blood buffering (Lemann et al., 2003), and increased urinary proton loss for acid disposal. Respiratory frequency increased in cows fed $\mathrm{T} 4$ and $\mathrm{T} 5$ diets, which probably explains the reduced $\mathrm{pCO}_{2}$ and $\mathrm{tCO}_{2}$ in cows in those diets. Charbonneau et al. (2006) clearly showed that reducing the DCAD also reduced $\mathrm{pCO}_{2}$ supporting the compensated respiratory alkalosis triggered by the diet-induced metabolic acidosis. This is in an attempt to compensate the metabolic acidosis by increasing the loss of $\mathrm{CO}_{2}$ by increased respiration rate. It is interesting that supplementing $\mathrm{Cl}$ salts to the alkalogenic or the acidogenic diet resulted in changes in acid-base balance that favored a reduction in blood $\mathrm{pH}$ or in base excess. These reductions were small, but suggestive that bioavailability of $\mathrm{Cl}$ in $\mathrm{NaCl}$ or $\mathrm{KCl}$ might be greater than that of the cations in the salts.

Cows fed diets that induced metabolic acidosis had increased concentrations of $\mathrm{K}$ in blood. Redistribution of blood K under metabolic acidosis is a well-characterized phenomenon and associated with changes in $\mathrm{Na}^{+} /$ $\mathrm{H}^{+}$exchanger that affect the $\mathrm{Na}^{+} / \mathrm{K}^{+}$pump (Aronson and Giebisch, 2011). Under metabolic acidosis, the $\mathrm{Na}^{+} / \mathrm{H}^{+}$exchanger is suppressed leading to accumulation of intracellular $\mathrm{H}^{+}$and a reduction in intracellular $\mathrm{Na}^{+}$content. These changes reduce the uptake of $\mathrm{K}^{+}$ by the cells through the $\mathrm{Na}^{+} / \mathrm{K}^{+}$ATPase, resulting in increased $\mathrm{K}$ concentrations in blood. Also, metabolic acidosis induced by increased $\mathrm{Cl}$ intake reduces extracellular $\mathrm{HCO}_{3}^{-}$, which increases the influx of $\mathrm{Cl}^{-}$into the cytosol of cells by the $\mathrm{Cl}^{-} / \mathrm{HCO}_{3}{ }^{-}$exchanger. The increased intracellular $\mathrm{Cl}^{-}$favors an efflux of intracellular $\mathrm{K}^{+}$, which contributes to the plasma pool (Aronson and Giebisch, 2011). The increases in blood concentrations of $\mathrm{Na}$ and $\mathrm{Cl}$ observed in the current experiment likely reflect the increased dietary intakes when cows received additional salts in the diet.

Feeding behavior of cows was altered by feeding acidogenic diets and the responses observed are likely associated with the depression in DMI induced by those diets. Intake of DM is a function of meal size and meal frequency. Davis et al. (2014), studying feeding behavior in beef steers, showed that DMI was positively related to the number of meals consumed and the size of each meal. Cows fed the acidogenic diets had longer but fewer meals, with no difference in meal size or eating rate. Meal size is a function of satiety and it seems that the changes in acid-base status induced by the level of negative DCAD fed did not result in earlier satiety during a meal. On the other hand, the longer intermeal interval suggests that hunger was delayed in cows fed the acidogenic diets. The longer intermeal interval that resulted in fewer daily meals likely explains the reduced DMI in cows fed T4 and T5. In lactating dairy cows, each extra meal was associated with a $0.19 \mathrm{~kg} / \mathrm{d}$ of additional DMI (Johnston and DeVries, 2018). Nevertheless, the underlying mechanism by which the change in acid-base balance resulting in metabolic acidosis affects appetite in cows remains unknown. Neuroendocrine control of appetite in ruminants is mediated by release 
of gut peptides, enteric neuronal communication with the brain, and hepatic ATP availability from substrate oxidation (Allen and Bradford, 2009). Mechanisms of how intake is influenced by oxidizable substrates are well described in the monogastric and ruminant literature, but little information is available on how metabolic acidosis might affect intake. In lactating cows, increasing the DCAD improves DMI, suggesting that acidbase balance can influence appetite in cattle (Iwaniuk et al., 2015). Acid-sensing ion channels are ubiquitous in mammalian nervous tissues and present in sensory neurons in the gastrointestinal tract or in the central nervous system (Ruffin et al., 2014). It is possible that changes in proton load is sensed by these acid-sensing ion channels and influence neuron excitability, which could potentially interfere with appetite. Nevertheless, the exact mechanism requires further investigation.

Feeding the acidogenic diet in T4 did not affect water intake; however, incorporation of salts containing $\mathrm{Cl}$ to alkalogenic or acidogenic diets increased water intake likely because of the osmotic effects of $\mathrm{NaCl}$ and $\mathrm{KCl}$. Murphy et al. (1983) showed that water intake in early lactation dairy cows increased by $50 \mathrm{~mL}$ for each additional gram of $\mathrm{Na}$ consumed, and cows in $\mathrm{T} 2$, $\mathrm{T} 3$, and $\mathrm{T} 5$ consumed more $\mathrm{Na}$ and more water than cows in $\mathrm{T} 1$ or $\mathrm{T} 4$. Also, diets in $\mathrm{T} 2$ and $\mathrm{T} 5$ were supplemented with $\mathrm{KCl}$, which also increases gastrointestinal fluid osmolality. Feeding additional $\mathrm{K}$ as $\mathrm{K}_{2} \mathrm{CO}_{3}$ to lactating cows increased water intake (Delaquis and Block, 1995). Therefore, the additional intake of salts that alter osmolality of the gastrointestinal content likely influenced osmolality of blood that affects hypothalamic osmoreceptors, thereby inducing thirst and water intake. The increased water intake explains the increased urinary volume in diets supplemented with salts containing $\mathrm{Cl}$. Although the experiment was not designed to evaluate BW changes, the small differences in BW and average daily gain observed with treatments were likely caused by increased water intake with added salts containing $\mathrm{Cl}$ than improved tissue weight gain. Cows fed T1 consumed only $4.1 \mathrm{~g} / \mathrm{d}$ of $\mathrm{Na}$, which is less than the suggested needed for pregnant dry cows (NRC, 2001). Because supplementing $1.0 \% \mathrm{NaCl}$ to the alkalogenic diet did not influence BW or ADG, it is unlikely that the short-term low $\mathrm{Na}$ intake in $\mathrm{T} 1$ was detrimental to performance. In fact, feeding lactating cows a diet with $0.4 \% \mathrm{Na}$ for $35 \mathrm{~d}$ did not affect DMI or milk yield (Thiangtum et al., 2011).

Cows fed the acidogenic diets had increased urinary loss of $\mathrm{Ca}$, which was not associated with $\mathrm{Ca}$ intake. Reabsorption of $\mathrm{Ca}$ from urinary filtrate is mediated by the transient receptor potential cation channel subfamily $\mathrm{V}$ member 5 (TRPV5) in the apical lumen of the distal convoluted tubules of the nephron (WoudenbergVrenken et al., 2009). Tubular acidosis induced by acidogenic diet increases $\mathrm{iCa}$ and proton flux through the filtrate, which reduces uptake of iCa by TRPV5, resulting in increased urinary loss of $\mathrm{Ca}$ (Yeh et al., 2003). On the other hand, urinary losses of $\mathrm{Na}, \mathrm{K}, \mathrm{S}$, and $\mathrm{Cl}$ were all linearly related to dietary intake of those minerals, although the relationship between the intake of net Eq of DCAD and the excretion of net Eq of SID in urine resulted in 2 distinctive clusters, one comprising of cows fed diets that induced metabolic acidosis and one fed alkalogenic diets.

Changes in acid-base status had only a minor effect on blood glucose concentrations, likely explained by the differences in DMI and subsequent substrate availability for gluconeogenesis. Nevertheless, the changes in acid-base status imposed by the dietary manipulations did not affect concentrations of free fatty acids, IGF1, or insulin. Severe metabolic acidosis might interfere with energy metabolism beyond the effects on nutrient intake. Uncompensated metabolic acidosis can induce insulin resistance and increased lipolysis (Hayata et al., 2014). A diet with $-405 \mathrm{mEq} / \mathrm{kg}$ of DM fed to Jersey cows resulted in blood $\mathrm{pH}$ of 7.31 and reduced insulin concentrations after an intravenous bolus of glucose (Bigner et al., 1996), thereby suggesting that feeding diets with excessive acidogenic potential might influence energy metabolism and impair insulin sensitivity. Chronic metabolic acidosis in humans induced by ammonium chloride disrupts the growth-hormone/IGF1 axis and reduces concentrations of IGF1 (Brüngger et al., 1997). Nevertheless, the metabolic acidosis induced by the diets with $-110 \mathrm{mEq} / \mathrm{kg}$ fed in $\mathrm{T} 4$ and $\mathrm{T} 5 \mathrm{did}$ not affect lipolysis in well-fed cows based on plasma free fatty acids, or concentrations of insulin or IGF1. Collectively, these data suggest that $2 \mathrm{wk}$ of a compensated metabolic acidosis does not disrupt energy metabolism because of changes in endocrine signals from the gut or impair insulin sensitivity. Surprisingly, addition of salts containing $\mathrm{Cl}$ either to the acidogenic or the alkalogenic diet increased concentrations of IGF1 in plasma. We are unaware of a potential mechanism for the effect of $\mathrm{NaCl}$ or $\mathrm{KCl}$ (or both) on concentrations of IGF1 in cattle.

\section{CONCLUSIONS}

Feeding an acidogenic product to reduce the DCAD of the diet fed to dry pregnant cows induced a compensated metabolic acidosis that depressed DMI. The depression in intake was mediated by the acid-base status of the cow, and not by the potential palatability issues that might arise from the inclusion of the acido- 
genic product. When the diet containing the acidogenic product also was supplemented with alkalogenic salts to result in the same positive DCAD as that of cows fed diets without any acidogenic product, then the depression in DMI was prevented. Changes in acid-base status mediated by metabolic acidosis resulted in minor changes in feeding behavior with a reduction in eating and chewing bouts, and extended meal duration and intermeal interval. Collectively, feeding acidogenic diets to dry pregnant cows reduces DMI because of metabolic acidosis, and not because of incorporation of acidogenic products or issues related to palatability of diet. Although diets might be formulated with acidogenic products considered palatable, these results indicate that if they induce metabolic acidosis such diets have the potential to suppress appetite. Nevertheless, it is possible that some acidogenic salts might be less palatable and further enhance the depression in intake in prepartum cows.

\section{ACKNOWLEDGMENTS}

The authors thank Todd Pritchard and staff of the University of Florida Dairy Unit (Hague, FL) for assistance with the experiment. Partial support for the experiment was provided by Arm and Hammer Animal Nutrition.

\section{REFERENCES}

Allen, M. S., and B. J. Bradford. 2009. Control of eating by hepatic oxidation of fatty acids. A note of caution. Appetite 53:272-273.

AOAC. 1990. Official Methods of Analysis. 15th ed. Assoc. Off. Anal. Chem., Arlington, VA.

Aronson, P. S., and G. Giebisch. 2011. Effects of $\mathrm{pH}$ on potassium: New explanations for old observations. J. Am. Soc. Nephrol. 22:1981-1989.

Bigner, D. R., J. P. Goff, M. A. Faust, J. L. Burton, H. D. Tyler, and R. L. Horst. 1996. Acidosis effects on insulin response during glucose tolerance tests in Jersey cows. J. Dairy Sci. 79:2182-2188.

Block, E. 1984. Manipulating dietary anions and cations for prepartum dairy cows to reduce incidence of milk fever. J. Dairy Sci. 67:2939-2948.

Box, G. E. P., and D. R. Cox. 1964. An analysis of transformations. J. Royal Stat. Soc. B. 26:211-252.

Brüngger, M., H. N. Hulter, and R. Krapf. 1997. Effect of chronic metabolic acidosis on the growth hormone/IGF-1 endocrine axis: New cause of growth hormone insensitivity in humans. Kidney Int. $51: 216-221$.

Charbonneau, E., D. Pellerin, and G. R. Oetzel. 2006. Impact of lowering dietary cation-anion difference in nonlactating dairy cows: A meta-analysis. J. Dairy Sci. 89:537-548.

Chizzotti, M. L., S. C. Valadares Filho, R. F. D. Valadares, F. H. M. Chizzotti, and L. O. Tedeschi. 2008. Determination of creatinine excretion and evaluation of spot urine sampling in Holstein cattle. Livest. Sci. 113:218-225.

Curtis, C. R., H. N. Erb, C. J. Sniffen, R. D. Smith, P. A. Powers, M. C. Smith, M. E. White, R. B. Hillman, and E. J. Pearson. 1983 Association of parturient hypocalcemia with eight periparturient disorders in Holstein cows. J. Am. Vet. Med. Assoc. 183:559-561.

Davis, M. P., H. C. Freetly, L. A. Kuehn, and J. E. Wells. 2014. Influence of dry matter intake, dry matter digestibility, and feed- ing behavior on body weight gain of beef steers. J. Anim. Sci. 92:3018-3025.

Delaquis, A. M., and E. Block. 1995. Acid-base status, renal function, water, and macromineral metabolism of dry cows fed diets differing in cation-anion difference. J. Dairy Sci. 78:604-619.

Dias, A. L., J. A. Freitas, B. Micai, R. A. Azevedo, L. F. Greco, and J. E. P. Santos. 2018. Effects of supplementing yeast culture to diets differing in starch content on performance and feeding behavior of dairy cows. J. Dairy Sci. 101:186-200.

Ender, F., I. Dishington, and A. Helgebostad. 1971. Calcium balance studies in dairy cows under experimental induction and prevention of hypocalcaemic paresis puerperalis. Z. Tierphysiol. Tierernahr. Futtermittelkd. 28:233-256.

Goff, J. P. 2008. The monitoring, prevention, and treatment of milk fever and subclinical hypocalcemia in dairy cows. Vet. J. 176:50-57.

Goff, J. P., R. Ruiz, and R. L. Horst. 2004. Relative acidifying activity of anionic salts commonly used to prevent milk fever. J. Dairy Sci $87: 1245-1255$

Hall, M. B. 2015. Determination of dietary starch in animal feeds and pet food by an enzymatic colorimetric method: collaborative study. J. AOAC Int. 98:397-409.

Hayata, H., H. Miyazaki, N. Niisato, N. Yokoyama, and Y. Marunaka 2014. Lowered extracellular $\mathrm{pH}$ is involved in the pathogenesis of skeletal muscle insulin resistance. Biochem. Biophys. Res. Commun. 445:170-174.

Iwaniuk, M. E., A. E. Weidman, and R. A. Erdman. 2015. The effect of dietary cation-anion difference concentration and cation source on milk production and feed efficiency in lactating dairy cows. J. Dairy Sci. 98:1950-1960.

Johnston, C., and T. J. DeVries. 2018. Short communication: Associations of feeding behavior and milk production in dairy cows. J. Dairy Sci. 101:3367-3373.

Jørgensen, E., and A. R. Pedersen. 1998. How to obtain those nasty standard errors from transformed data-And why they should not be used. Page 20 in Biometry Research Unit - Internal Report 7, Danish Institute of Agricultural Sciences, Aarhus, Denmark.

Joyce, P. W., W. K. Sanchez, and J. P. Goff. 1997. Effect of anionic salts in prepartum diets based on alfalfa. J. Dairy Sci. 80:28662875

Lemann, J., D. A. Bushinsky, and L. L. Hamm. 2003. Bone buffering of acid and base in humans. Am. J. Physiol. Renal Physiol 285:F811-F832.

Lopera, C., R. Zimpel, A. Vieira-Neto, F. R. Lopes, W. Ortiz, B. N. Faria, M. L. Gambarini, M. Poindexter, E. Block, C. D. Nelson, and J. E. P. Santos. 2018. Effects of level of dietary cation-anion difference and duration of prepartum feeding on performance and metabolism of dairy cows. J. Dairy Sci. 101:7907-7929. https://doi .org/10.3168/jds.2018-14580.

Maltz, E., L. F. Barbosa, P. Bueno, L. Scagion, K. Kaniyamattam, L. F. Greco, A. de Vries, and J. E. P. Santos. 2013. Effect of precision feeding on performance, nutrient excretion and feeding behavior of early lactation dairy cows. J. Dairy Sci. 96:5249-5266.

Martinez, N., C. A. Risco, F. S. Lima, R. S. Bisinotto, L. F. Greco, E. S. Ribeiro, F. Maunsell, K. Galvão, and J. E. P. Santos. 2012. Evaluation of peripartal calcium status, energetic profile, and neutrophil function in dairy cows at low or high risk of developing uterine disease. J. Dairy Sci. 95:7158-7172.

Martinez, N., R. M. Rodney, E. Block, L. L. Hernandez, C. D. Nelson, I. J. Lean, and J. E. P. Santos. 2018a. Effects of prepartum dietary cation-anion difference and source of vitamin D on dairy cows: lactation performance and energy metabolism. J. Dairy Sci. 101:2544-2562.

Martinez, N., R. M. Rodney, E. Block, L. L. Hernandez, C. D. Nelson, I. J. Lean, and J. E. P. Santos. 2018b. Effects of prepartum dietary cation-anion difference and source of vitamin D on dairy cows: Health and reproductive responses. J. Dairy Sci. 101:2563-2578.

Murphy, M. R., C. L. Davis, and G. C. McCoy. 1983. Factors affecting water consumption by Holstein cows in early lactation. J. Dairy Sci. 66:35-38.

NRC. 2001. Nutrient Requirements of Dairy Cattle. 7th rev. ed. National Academy Press, Washington, DC. 
Oetzel, G. R., and J. A. Barmore. 1993. Intake of a concentrate mixture containing various anionic salts fed to pregnant, nonlactating dairy cows. J. Dairy Sci. 76:1617-1623.

Oetzel, G. R., J. D. Olson, C. R. Curtis, and M. J. Fettman. 1988. Ammonium chloride and ammonium sulfate for prevention of parturient paresis in dairy cows. J. Dairy Sci. 71:3302-3309.

Rodney, R. M., N. Martinez, E. Block, L. L. Hernandez, C. D. Nelson, P. Celi, J. E. P. Santos, and I. J. Lean. 2018. Effects of prepartum dietary cation-anion difference and source of vitamin D in dairy cows: vitamin D, mineral, and bone metabolism. J. Dairy Sci. 101:2519-2543.

Ruffin, V. A., A. I. Salameh, W. F. Boron, and M. D. Parker. 2014. Intracellular $\mathrm{pH}$ regulation by acid-base transporters in mammalian neurons. Front. Physiol. 5:43.

Santos, J. E. P., H. M. Golder, E. Block, and I. J. Lean. 2018. Metaanalysis of the effects of prepartum dietary cation-anion difference on performance and health of dairy. J. Dairy Sci. 101(Suppl. 2):413 (Abstr.).

Tebbe, A. W., and W. P. Weiss. 2018. Evaluation of creatinine as a urine marker and factor affecting excretion of magnesium by dairy cows. J. Dairy Sci. 101:5020-2032.
Thiangtum, W., A. Yawongsa, J. T. Schonewille, T. Rukkawamsuk, C. Yuaglang, M. W. A. Verstegen, and W. H. Hendriks. 2011. An attempt to define the sodium requirements of lactating dairy cows in tropical environment. J. Sci. Food Agric. 91:2333-2337.

USDA. 2016. Dairy 2014, dairy cattle management practices in the United States. Accessed Feb. 10, 2018. https://www.aphis.usda .gov/animal_health/nahms/dairy/downloads/dairy14/Dairy14 _dr_PartI.pdf.

Vagnoni, D. B., and G. R. Oetzel. 1998. Effects of dietary cationanion difference on the acid-base status of dry cows. J. Dairy Sci. 81:1643-1652.

Van Soest, P. J., J. B. Robertson, and B. A. Lewis. 1991. Methods for dietary fiber, neutral detergent fiber and nonstarch polysaccharides in relation to animal nutrition. J. Dairy Sci. 74:3583-3597.

Woudenberg-Vrenken, T. E., R. J. Bindels, and J. G. Hoenderop. 2009. The role of transient receptor potential channels in kidney disease. Nat. Rev. Nephrol. 5:441-449.

Yeh, B. I., T. J. Sun, J. Z. Lee, H. H. Chen, and C. L. Huang. 2003. Mechanism and molecular determinant for regulation of rabbit transient receptor potential type 5 (TRPV5) channel by extracellular pH. J. Biol. Chem. 278:51044-51052. 